NBER WORKING PAPER SERIES

\title{
HIGH-SKILLED MIGRATION AND AGGLOMERATION
}

\author{
Sari Pekkala Kerr \\ William Kerr \\ Çağlar Özden \\ Christopher Parsons \\ Working Paper 22926 \\ http://www.nber.org/papers/w22926 \\ NATIONAL BUREAU OF ECONOMIC RESEARCH \\ 1050 Massachusetts Avenue \\ Cambridge, MA 02138 \\ December 2016
}

Sari Pekkala Kerr is Senior Research Scientist, Wellesley Centers for Women, Wellesley College, Wellesley, Massachusetts. William Kerr is MBA Class of 1975 Professor of Entrepreneurial Management, Harvard Business School, Boston, Massachusetts, and Faculty Research Associate, National Bureau of Economic Research, Cambridge, Massachusetts. Çağlar Özden is Lead Economist, Development Research Group, World Bank, Washington, DC. Christopher Parsons is Assistant Professor of Economics, University of Western Australia, Perth, Australia, and Research Associate, International Migration Institute, University of Oxford, Oxford, UK. This research is generously supported by the Alfred Sloan Foundation, the International Migration Institute, the Kauffman Foundation, the National Science Foundation, Harvard Business School, and by the World Bank through the Knowledge for Change Program. William Kerr is a Research Associate of the Bank of Finland and thanks the Bank for hosting him during a portion of this project. The views expressed herein are those of the authors and do not necessarily reflect the views of the National Bureau of Economic Research.

NBER working papers are circulated for discussion and comment purposes. They have not been peer-reviewed or been subject to the review by the NBER Board of Directors that accompanies official NBER publications.

(C) 2016 by Sari Pekkala Kerr, William Kerr, Çağlar Özden, and Christopher Parsons. All rights reserved. Short sections of text, not to exceed two paragraphs, may be quoted without explicit permission provided that full credit, including (C) notice, is given to the source. 
High-Skilled Migration and Agglomeration

Sari Pekkala Kerr, William Kerr, Çağlar Özden, and Christopher Parsons

NBER Working Paper No. 22926

December 2016

JEL No. F15,F22,J15,J31,J44,L14,L26,O31,O32,O33

\section{ABSTRACT}

This paper reviews recent research regarding high-skilled migration. We adopt a data-driven perspective, bringing together and describing several ongoing research streams that range from the construction of global migration databases, to the legal codification of national policies regarding high-skilled migration, to the analysis of patent data regarding cross-border inventor movements. A common theme throughout this research is the importance of agglomeration economies for explaining high-skilled migration. We highlight some key recent findings and outline major gaps that we hope will be tackled in the near future.

Sari Pekkala Kerr

Wellesley College

106 Central Street

Wellesley, MA 02481

skerr3@wellesley.edu

William Kerr

Harvard Business School

Rock Center 212

Soldiers Field

Boston, MA 02163

and NBER

wkerr@hbs.edu
Çağlar Özden

$1818 \mathrm{H}$ street NW

The World Bank

MC3-303 DECRG

Washington, DC 20433

cozden@worldbank.org

Christopher Parsons

Economics (UWA Business School)

The University of Western Australia (M251)

35 Stirling Highway

CRAWLEY WA 6009, Australia

christopher.parsons@uwa.edu.au 


\section{Introduction}

There is a global race for talent underway but outcomes are asymmetric. Individuals with valuable skills have a higher propensity to migrate both domestically and abroad, due to the exceptional returns they can earn. They frequently have the option to select from a menu of destinations. Yet, not all potential destinations are equally attractive in their professional and social opportunities. Countries differ in their accessibility and the degree to which they welcome foreigners. In addition to government policies, firms and institutions of higher education play crucial roles in the development of skills and the admissions decisions of many countries. While there is a complex web of actors involved, the central outcome is clear - the flows of high-skilled migrants are very concentrated, both within and across national borders. ${ }^{1}$

Many examples illustrate the prominence of the issues surrounding high-skilled migration. Advocates of reform towards high-skilled migration have adopted the phrase "national suicide" to describe current policies in the United States. The high-profile H-1B program, described further below, was one of the few specific policies discussed in recent presidential debates. Around the globe, demographic pressures in Europe, Japan and China necessitate building a stronger future workforce through attracting global talent as older populations shrink and public coffers face massive pressure. In the business landscape, highprofile start-ups like Skype, Uber and Rocket Internet vault overnight to globally distributed companies, rather than waiting to expand as they mature. They can only achieve such meteoric rise with a global workforce. Many multinational corporations actually operate with a minority of their workers in their headquarters country.

Our review focuses upon the agglomeration economies that undergird the asymmetric flows of highskilled migration, which result in the significant agglomeration that can be observed both domestically and internationally. We adopt a data-driven perspective, and Section 2 begins by describing newly available data that are being brought to bear on the phenomenon, which is much needed given the poor information historically available. We argue that the patterns of high-skilled migration are quite consistent with agglomeration economies, such as the broad flows from a large number of source countries to very few destination countries. These data further show that migration selection processes for skill are becoming sharper and increasingly involve female migrants. These new patterns, documented in Section 3 , complement core areas of past research on migrant networks and the contributions of high-skilled migrants to innovation in destination countries. In these cases, high-skilled migration does not dampen future incentives for migration, as would be the case if overseas opportunities were mostly linked to skilled workers complementing unskilled workers or other fixed factors, but instead further increases the incentives for others.

Section 4 then describes how traditional migration theories are able to explain parts of high-skilled migration well, while at the same time missing important ingredients. For example, a significant share of high-skilled migration also takes place via the skill-building process fostered by institutions of higher learning. In these cases, initial migration and selection is more about raw talent than formal skills. Foreign students and scholars flock to the universities in countries like the United States and the United Kingdom,

\footnotetext{
${ }^{1}$ Although the term "agglomeration" has several connotations, we use it throughout the paper to refer to this concentration.
} 
and the same individuals are later hired by domestic companies upon graduation. Lowell (2015) shows that the United States attracts by far the largest number of international students. In science, technology, engineering, and mathematics (STEM) subjects, the United States is close to the top in terms of the percentage of those students who are international. These and other factors noted in Section 4 can contribute to agglomeration economies taking deep root and building upon themselves in certain locations due to high-skilled migration.

Given these externalities, many countries are launching new policies to attract high-skilled migrants. Examples include the United Kingdom's introduction of a points-based immigration system under Tony Blair's government and its recent programs to attract the "brightest and best" innovators and entrepreneurs. The Netherlands introduced a new "Expatcenter Procedure," which is an entry procedure designed for "knowledge migrants." Competing programs pop up with regular frequency —in short, the doors seem to be opening ever wider for high-skilled migrants (with perhaps the partial exception of the United States, where policy moves little). Section 5 analyses newly available data that detail high-skilled migration policies, while providing new insights into the heterogeneity of high-skilled migration flows along several dimensions. We use these data to shed light on how policy influences the rate and direction of migration flows and to describe open areas for further research.

Section 6 focuses on the implications of high-skilled migration for labor markets, social welfare, and inequality, and Section 7 considers important research areas that can help fill major gaps in our current knowledge. Substantial progress has been made on many issues related to labor markets, but much remains to be done. For example, global labor markets for high-skilled individuals are much more integrated than most people realize. Current research however fails to explore the distribution of skill (or human capital) across the globe in a unified manner. Most of the existing analyses are single-dimensional about a country's experience despite the impacts of high-skilled migration spanning international borders. We hope that some ideas presented here catalyze future work.

This review provides an in-depth analysis of available data and introduces several newly available data sources that are open to researchers. While of interest in its own right, these new data allow a critical appraisal of the existing literature and identify gaps that can now be addressed, illuminating where the next wave of research can go. Moreover, building upon policy recommendations grounded in research is important and countries need to understand the (often small) impacts of high-skilled migration policies on the actual selection of which high-skilled workers come to their countries (e.g., Czaika and Parsons forthcoming). Without proper attention to the school and work opportunities that high-skilled migrants pursue, the most aggressive policies will likely bear limited fruit for receiving countries. From the sending country perspective, research can help shed light on where brain drain is a real concern, where expatriates and diasporas can offer real advantages, and the factors that can help tilt the balance to the sending country's advantage. ${ }^{2}$

\footnotetext{
${ }^{2}$ This paper complements Kerr et al. (2016). This paper focuses more on data advances that describe migration stocks and flows, the agglomeration aspect of high-skilled migration and the theory behind it, recent data on migration policies and global implications of high-skilled migration. This paper also contains a more extensive set of references to the literature. Kerr et al. (2016) provide a higher-level introduction to patterns of talent flows across
} 


\section{Data Advances in High-Skilled Migration}

As is the case in every field of economics, migration research is dependent upon high-quality and publicly-available data. Yet the state of migration statistics, especially those pertaining to human capital, skills, education and labor markets, has been so much maligned that the discussions on these matters have become cliché and almost every paper starts with an apology. There is a long history of requests by researchers to the government officials on the data issue. Father of modern migration research Ernst Georg Ravenstein (1889) emphasized the importance of high-quality primary data from national sources as he established his so-called "laws" of human migration. Around the same time, experts at the International Statistical Institute meetings in Vienna in 1891 argued for the standardization and open dissemination of immigrant stock data (Falkner 1895, Santo Tomas et al. 2011). Over the following century, many calls by international organizations and academics have echoed the same pleas, culminating with United Nations' detailed Recommendations on Statistics of International Migration (1949, 1980 and 1998). To a large extent these calls have borne very little fruit. ${ }^{3}$

Migration data remain startlingly poor, in absolute terms and relative to data on other metrics of global interlinkages. It is safe to say that we know more about a piece of clothing crossing an international border or a foreign equity transaction than we do about an average migrant. This weakness is not just a loss for academic research. Effective policy depends upon high-quality data and analysis, and governments currently end up making decisions with far-reaching implications for their citizens and immigrants using very coarse data. Against this pessimistic backdrop, however, there is an exceptional surge of new information and data resources regarding high-skilled migration over the last decade, which hold the potential to dramatically push forward the boundaries of academic research and policy analysis.

Since the focus of this article is on the skill and education dimensions of international migration, we pay particular attention to data sources that include these dimensions. We can split the noteworthy data sources into two main categories. On one hand, there are the new databases of international migration stocks by bilateral country pairs and disaggregated by skill levels. These are, in essence, large compilations of census and population register data collected from destination countries around the world and aim to provide a comparable picture of skill mobility. These databases tend to take two forms. The first wave of projects focused on destination countries that were members of the OECD. The main reasons for this focus were increased demand from policymakers in these countries as well as availability of comparable and higher-quality data. These efforts have been spearheaded by the World Bank and the OECD. ${ }^{4}$ By focusing upon OECD countries, databases can include more detailed information (e.g., finer skill/education categories, occupations, age distributions, etc.).

countries and focuses more upon national gatekeepers for high-skilled migration. It describes more deeply approaches used to select migrants for admission and compares several Anglo-Saxon economies in this regard.

${ }^{3}$ There are numerous reasons behind governments' reluctance or inability to collect and disseminate high-quality and high-frequency migration data. These range from budget constraints to governments' treatment of these data as matters of national security. The discussion of these issues deserves a separate review article.

${ }^{4}$ Important work here is Dumont and Lemaître (2005), Docquier and Marfouk (2006), Beine et al. (2007), Dumont et al. (2007), Docquier et al. (2009), Widmaier and Dumont (2011), and Arslan et al. (2014). 
The second wave focuses on establishing the overall global picture of international human-capital movements (e.g., Artuç et al. 2015). This approach acknowledges the inherent differences in recording practices across countries and does its best to harmonize different definitions (e.g., migrants, education). They mostly start with OECD-centric data, add available data from non-OECD countries, and then implement econometric methods to fill in the gaps where data are otherwise unavailable. The primary goal is to construct a complete mapping of migration patterns by skill/education levels. These two approaches are comparable to the development of maps over the centuries. Some maps focus on establishing global portraits and include all important details, even if they might be quite inaccurate about the exact shapes of less-explored continents (like Africa) and other geographic elements. Other maps focus on organizing and representing only high-quality details such as those for European countries or well-explored areas. In between these extremes lie hybrids like the DIOC-E database of the OECD, which comprises primary data disaggregated by education level from both OECD and non-OECD countries.

The construction and dissemination of the bilateral datasets provide the most accurate and up-to-date picture of global human capital mobility. Yet, by the time the underlying decennial census data have been collected, compiled, harmonized by the national statistical agencies, and then put together into global migration databases by international agencies, they are many years out of date. This is where the second main category of databases and related studies enters the picture. More frequent and/or topical data can be obtained from global or country-level surveys or from national administrative data sources that focus on particular corridors (say, from India to the Persian Gulf countries) or occupations. To the best of our knowledge, the only harmonized dataset of bilateral migration flows by skill level is that detailed in Czaika and Parsons (2016) and analyzed in Czaika and Parsons (forthcoming). Examples of the latter include databases on doctors (Clemens and Pettersson 2008, Bhargava et al. 2011), foreign-born scientists (Franzoni et al. 2012), Indian academics (Czaika and Toma 2013) or inventor mobility (Miguelez and Fink 2013). ${ }^{5}$ These focused data sources and studies are highly valuable for answering narrower questions and setting the stage for global projects, but one needs to be careful in extending and generalizing their conclusions.

\section{Global High-Skilled Migration Patterns}

The data advances listed above provide a far more accurate portrait of high-skilled migration patterns than what was previously possible, and we review these patterns next. Researchers have investigated some of these observed regularities, but in other cases the data suggest that deeper inquiries are warranted. Below, we document features that are critical to high-skilled migration, including migrant selection from origin nations and into destination nations, the shift toward agglomeration of global talent into a few OECD countries from an ever-larger base of origin countries, and the meteoric rise of high-skilled female migration. Our companion paper, Kerr et al. (2016), provides complementary patterns and certain statistics that we do not repeat.

\footnotetext{
${ }^{5}$ The global migration of inventors, and their resulting concentration in a handful of countries, is particularly well documented. Examples include Stephan and Levin (2001), Kerr (2008), Stephan (2010), Hunt and Gauthier-Loiselle (2010), Kerr and Lincoln (2010), Agrawal et al. (2011), Stuen et al. (2012), Ozgen et al. (2011), Parrotta et al. (2014), Bosetti et al. (2013), Miguelez and Fink (2013), Breschi et al. (2014, 2015), and Nathan (2015).
} 
Our data cover the period 1990-2010 and combine the datasets described in detail in Docquier et al. (2009) and Arslan et al. (2014). A migrant is defined as high-skilled if he or she has completed at least one year of tertiary education. The older OECD databases historically comprise individuals aged 15 and over, while those from the World Bank typically capture working ages of 25 and over. The 2010 OECD data collect detailed information on age distribution that allow better comparison, and we further match these data on the basis of their definition of migration, either country of birth or nationality. Our primary dataset comprises 29 OECD destinations and 194 origins. $^{6}$

The emigration rates of college-educated individuals are always greater than their lesser-educated compatriots across all countries and at every level of development (as measured by per capita incomes), as shown non-parametrically by Dao et al. (2016). There are several reasons behind this pattern. First, high-skilled people are more likely to be endowed with skills that are both in demand and globally transferrable. They are able to obtain job offers in advance of emigrating and clearing migration policy hurdles that favor higher levels of human capital. If they are using other migration channels (such as family preferences or lotteries), they know they will find employment or assimilate more easily upon their arrival. In addition, high-skilled migrants generally integrate into the host societies more easily as they are more likely to have better linguistic and cultural as well as professional knowledge of the destination society. Second, high-skilled individuals are more likely to be aware of the opportunities available to them in other countries. They have better access to global information sources, for example, through their social and professional networks. Third, high-skilled people can better access financial resources and credit. As a result, they are able to meet the financial costs of migration more easily. The highest skilled emigration rates are observed from middle income countries, in which natives are able to surmount migration costs (unlike many residents in poorer countries) whilst also having incentives to emigrate (unlike many residents of richer countries).

Figure 1a plots the share of high-skilled people in the native population against the share of high-skilled people in the emigrant population for 2010 , with circle diameter indicating a country's population. A $45^{\circ}$ line is drawn for ease of representation, such that all countries that lie above the line exhibit positive selection of emigration from the native population in terms of skills. This positive selection is far more pronounced from poorer origin countries, with the emigration rates of college-educated being around 30 times higher than those of the less-skilled. We also see strong selection in the two most populous countries, China and India. There are only a few countries like Mexico and Russia, which lie below the $45^{\circ}$ line, indicating their less-skilled workers are more likely to migrate. Given its prominence, the economics literature has extensively studied the negative selection from Mexico to the United States (e.g., Chiquiar and Hanson 2005, McKenzie and Rapoport 2010, Moraga 2011), and Figure 1a illustrates that this pattern is an exception to the general rule.

Figure $1 \mathrm{~b}$ analyzes whether incoming immigrants are more or less educated than the resident native population among our OECD sample (i.e., immigrant selection). Many of these high-income destination countries exhibit positive selection, which reflects their policy efforts to attract and screen for high-skilled

\footnotetext{
${ }^{6}$ The count of 29 destinations is fewer than the OECD total, as we exclude Chile, Estonia, Israel, Slovenia and South Korea to afford data harmonization. Our migrant selection analysis includes 144 countries when our migration data are combined with the Barro and Lee (2013) data on the education levels of natives.
} 
workers. Moreover, almost all of the negative-selection countries are quite close to the $45^{\circ}$ line, indicating that any observed negative selection is quite weak. The most notable exception is the United States, which is the world's most prominent destination for high-skilled migrants, yet admits a migrant population that is on average less skilled than its native population. This is partly due to the fact that Americans are more educated than the native populations of most OECD countries. Interestingly, the four Anglo-Saxon countries that attract the highest proportions of high-skilled migrants - Canada, the United Kingdom, Australia and New Zealand - implement points-based systems to varying degrees, which we discuss later in the policy section. Finally, we note that Mexico also has a noticeable positive immigrant selection.

\{Figures 1a and 1b. Emigrant and Immigrant Selection, 2010\}

The patterns observed in Figures $1 \mathrm{a}$ and $1 \mathrm{~b}$ are closely linked to the sharp rise in the overall number of high-skilled migrants to OECD countries, which increased by 120\% from 12 million in 1990 to 27 million in 2010 (Kerr et al. 2016). Figures 2a and 2b document changes in emigrant and immigrant selection, respectively, during this period. There does not appear to be a systematic trend in emigrant selection (Figure 2a), with approximately half of the origin countries on either side of the $45^{\circ}$ line. By contrast, most OECD destination countries show greater skill selection in 2010 than 1990 (Figure 2b). This pattern aligns with observations that the immigration policies of many destination countries are becoming increasingly selective (e.g., de Haas et al. 2014). For example, we see that Canada is consistently selective, while the United Kingdom demonstrates the largest increase in selectivity. The United States is again a notable exception, along with Italy, Portugal, and New Zealand, falling somewhat below the $45^{\circ}$ line. ${ }^{7}$

\{Figures 2a and 2b. Changes in Emigrant and Immigrant Selection, 1990-2010\}

As a result of increasing global integration and rising education levels, the number of "empty" highskilled migration corridors (i.e., those along which no migrants travel whatsoever) in 2010 totaled just $15 \%$ of all potential corridors in our data $(631$ of the 4,176$)$. This represents a $50 \%$ decline in zero-valued cells since 1990. Over the same period, the average high-skilled migration corridor increased by $127 \%$ to almost 6,400 individuals. A natural implication of these trends is that high-skilled migrant stocks are becoming more diversified over time, which can yield developmental benefits (Alesina et al. 2016). ${ }^{8}$ Herfindahl indices show a lower concentration of origin countries for high-skilled workers than lowskilled workers. Moreover, since 1990, the high-skilled migrants in OECD countries have hailed from an increasingly wide set of origin countries. By contrast, lower-skilled migrants in OECD countries are increasingly arriving from fewer origin countries.

\footnotetext{
${ }^{7}$ The higher selectivity in Figure $2 \mathrm{~b}$ can be reconciled with the limited trend in Figure $2 \mathrm{a}$ when one observes that very populous countries like China and India lie above the $45^{\circ}$ line in Figure 2a. It is also interesting to note that the negative selection to emigration from Mexico is becoming more pronounced with time.

${ }^{8}$ Global firms seek to draw talent from around the world, often with the perspective or claim that they cannot find adequate pools of talent in their home countries. Labor market shortfalls can arise due to factors such as rapidly increasing demand, limited training capacity and extended length of training. Medical professions are the most prominent examples of these constraints. The recruitment of migrants to fill such gaps can result in far more diverse high-skilled work forces.
} 
Figure 3 further shows that high-skilled migrants tend to travel farther to their destination countries than their less-skilled compatriots. This graph shows the cumulative distribution of distances travelled by migrants of different skill levels in 2010. We rank each bilateral corridor by the distance between them and tabulate the cumulative share of migration as we add more-distant corridors. The figure reveals that the median distance travelled by a high-skilled migrant is 7,000 miles, while it is below 4,000 for lowskilled migrants. ${ }^{9}$

\{Figure 3: Cumulative Distribution of Migration Distance, 2010$\}$

Another stark and first-order trend is the significant agglomeration of high-skilled migrants. Artuç et al. (2015) estimate that around two-thirds of all international high-skilled migrants resided in OECD countries in 2000, despite these countries collectively constituting less than one-fifth of the world's population. Furthermore, the distribution is exceptionally asymmetric even within the OECD. Four Anglo-Saxon countries - the United States, Canada, Australia and the United Kingdom-host over twothirds of all high-skilled immigrants in the OECD. This particular concentration has somewhat declined with time, but still remains exceptionally strong. ${ }^{10}$

Agglomeration of talent is a natural phenomenon that also happens within countries. Figure 4 plots the sharp regional concentrations of high-skilled migrants in the United States in 2010. Significant concentrations of high-skilled migrants occur in Boston, Northern and Southern California, Chicago, New York City, Miami and Seattle, among others. Such patterns are reflected globally, with capital cities (e.g., London) and large clusters hosting the substantial majority of high-skilled migrants in each country. Related to their geographic concentration, high-skilled migrants also agglomerate by occupation or sector. This can reflect migration responding to domestic shortfalls in native skills or migrants concentrating in occupations and industries that benefit from agglomeration or diaspora networks. Innovation areas of the United States (such as Silicon Valley, Boston or Seattle) tend, for example, to show higher levels of immigrant concentration in science and engineering professions compared to other areas (Silicon Valley Competitiveness Report 2016).

\{Figure 4: Distribution of High-Skilled Migrants in USA, 2010\}

As stark and asymmetric as these high-skilled patterns are, they become even more accentuated at the very highest skill levels (Wasmer et al. 2007, Akcigit et al. 2016). This is true in almost every highskilled profession, in academia, entertainment, entrepreneurship, literature, medicine, science and sports. Migrants have won half of the 56 Fields Medals, awarded every four years for outstanding achievements in mathematics, including the most recent award to the first female winner, Iranian-American Maryam Mirzakhani. One-third (15/46) of the Man Booker prize winners, a prestigious literary prize awarded to fiction published in the English language, are immigrants (e.g., Salman Rushdie, V.S. Naipaul). Kerr et

\footnotetext{
${ }^{9}$ By contrast, the differences in step size of the GDP per capita between home and host country are more similar across skill levels.

${ }^{10}$ Readers interested in an additional analysis of migrant concentrations are referred to Özden and Parsons (2016).
} 
al. (2016) provide similar statistics for Nobel Prizes and the John Bates Clark medal, as well as examples from sports ranging from the NBA to the English Premier League. ${ }^{11}$

Another important but much understudied feature of high-skilled migration is the rapid rise of highskilled female migration. From 1990 to 2010, the migration of high-skilled females to OECD countries rose by $157 \%$, compared to $106 \%$ for males. By 2010 , the total number of high-skilled female migrants outnumbered high-skilled male migrants. As a proportion of total high-skilled migration, females accounted for a higher percentage across every OECD destination with the exception of Spain, although three other Southern European countries exhibited the largest overall proportions Greece (60\%), Portugal $(60 \%)$ and Italy $(65 \%)$. Mirroring this trend in destination countries is the significant feminization of high-skilled emigration from almost all origin countries in the world, as shown in Figure 5.

\{Figure 5: Change in Selection on Gender in High-Skilled Emigration, 1990-2010\}

\section{Demand Factors Shaping High-Skilled Migration Flows}

What lies behind these high-skilled migration patterns? As early as Smith (1776), economists have discussed the movement of workers to take advantage of higher wage opportunities. The theoretical framework for studying human-capital flows has its beginnings in 1932, when John Hicks noted that "...differences in net economic advantages, chiefly differences in wages, are the main causes of migration" (Hicks 1932). ${ }^{12}$ The standard textbook model used to explain the self-selection of immigrants by skill level is an adaptation of the Roy (1951) model. In Borjas' (1987) version of the Roy model, there is a skill-distribution of individuals in both the destination and the source countries. Individuals' migration decisions are governed by the relative returns to their skills in both locations, as well as the migration costs they face. Depending on the shapes of the skill-earnings locus and migration costs, positive, negative and intermediate selection are possible. As one illustration of these models, Figure 6 shows a simple graphical example adapted from Chiquiar and Hanson (2005) of intermediate selection arising from non-linear returns to skill in the destination country (US) and fixed migration costs across skill groups. Individuals with a skill level between $\mathrm{SL}^{*}$ and $\mathrm{SU}^{*}$ will choose to migrate, whereas those with greater or weaker skill levels will not.

\{Figure 6: Self-Selection of Immigrants by Skill - Intermediate Case\}

Grogger and Hanson $(2013,2015)$ emphasize that immigrant selection and sorting are important features in the high-skilled migration phenomenon. Selection (as described above) refers to how migrants are chosen from the skill distribution of the origin country, and sorting is about how these migrants choose among potential destination countries. In the simplest case, the relative return to skill across countries

\footnotetext{
${ }^{11}$ In an advocacy piece, Anderson (2013) calculates that more than $40 \%$ of Fortune 500 companies were founded by immigrants or their children, with some $18 \%$ being founded directly by first-generation immigrants. Broader studies for the United States tend to find evidence for immigrants being more entrepreneurial (e.g., Hunt 2011, Fairlie and Lofstrom 2014, Kerr and Kerr 2016).

${ }^{12}$ Sjaastad (1962) and Neal and Uselding (1972) are examples of early work on human capital and migration decisions.
} 
(i.e., differences in wage-skill premiums) determines the skill composition of the migrant flows between any pair of countries. Individuals with the highest skill levels tend to migrate to countries with higher earnings variance to receive the greatest wages. This can explain why, for example, the United States and Canada receive a much larger share of high-skilled migrants compared to European countries, where the earnings distributions are more compressed.

How economic growth and changes in migration regimes impact migrant flows depends upon the shape of the skill-earnings locus. With linear skill-earnings profiles and positive selection, for example, overall wage growth in the host country shifts the skill threshold for migration to the left. More people migrate from the source country, and the skill level of the average migrant falls. On the other hand, an increase in migration costs (e.g., a more demanding visa system) shifts the skill threshold to the right and thus increases the average skill composition of migrants.

If migration costs are not proportional to earnings, but instead fixed across skill groups (e.g., the costs of a visa or work permit is identical across skill levels), the positive selection of emigrants becomes more likely (Borjas 1991, Chiquiar and Hanson 2005). Indeed, the role of migration costs is crucial for explaining why we observe very different patterns of selection of emigrants from China and India versus Puerto Rico to the United States. ${ }^{13}$ When migration costs are proportional to earnings, negative selection is more likely, as in the case of migration flows from India to the Persian Gulf States. On the other hand, where migration costs are fixed in nature, we tend to get a strongly positive selection of emigrants, as in the $\mathrm{H}-1 \mathrm{~B}$ visa program to the United States. ${ }^{14}$

The basic Roy framework can handle many scenarios and explain many of our observations. We focus on positive hierarchical sorting, where migrants are positively selected from the source-country skill distribution and fall into the upper half of the host-country skill distribution; this is the most empirically relevant scenario as described in the last section. The conditions for this type of selection require that the host country has higher returns to skill and that the skill demands of the host and the source country are highly correlated. These cases lead to strong talent flows from sending countries. Indeed, due to a wide earnings distribution and comparatively low taxation and low tax progressivity, the returns to skill are greater in the United States than most countries. Akcigit et al. (2016) connect these taxation features of countries to the global migration of very high quality inventors. This setting also makes clear why demand for South-to-North migration would be substantial from developing economies that have wage curves that sit completely below those in advanced countries. ${ }^{15}$

While powerful, the textbook Roy model of selection and sorting is insufficient to explain all aspects of high-skilled migration (even before considering admission decisions by countries). For example, the causes of the differences in wage profiles across countries are crucial when explaining persistence. Some

\footnotetext{
${ }^{13}$ Migration costs have been the focus of a recent wave of studies (e.g., Beine et al. 2011, Grogger and Hanson 2013, 2015, Docquier and Rapoport 2012).

${ }^{14}$ The migration cost literature also separates out actual moving and assimilation costs versus the cost of obtaining entry into the country in the form of a visa, citizenship or other means (e.g., Beine et al. 2011).

${ }^{15}$ Recent papers study historical settings where migration was a result of dire economic and social situations. Moser et al. (2014) examine the discharge of German Jewish chemists from Nazi Germany, and Borjas and Doran (2012) the fleeing of Russian mathematicians after the collapse of the Soviet Union. These refugee examples are one extreme form of selection when the economic opportunities in the source country collapse.
} 
differences arise since locations have different levels of financial and physical capital, technology, complementary workers and institutions. All of these factors impact the quality, productivity and resulting wages of the jobs present (Moretti 2012). General equilibrium effects of high-skilled migration may narrow the wage differences that prompt the initial movements of talent if they are due to relatively fixed factors. This would be particularly true if wage profile differences originate from workers of different skill levels complementing each other. In fact, this scenario can be the basis for the migration version of the Lucas paradox: Why doesn't human capital flow from rich to poor countries?

At this juncture, agglomeration effects and productivity spillovers enter the picture. With agglomeration effects, the presence of high-skilled people in a geographic location-regardless of whether they are natives or immigrants - may increase the incentives for additional high-skilled people to move there. This would be consistent with the patterns observed in the data. Many high-skilled occupations and sectors with high shares of migrants exhibit an agglomeration effect. Each individual's productivity is enhanced by the presence of or collaboration with other skilled workers employed in similar or related occupations and sectors. In fact, in the presence of agglomeration effects, migration of the highly skilled into a geographic area or sector need not lead to a decline in returns to skills or to wages. As a result, this mechanism can be quite self-reinforcing as embodied in the endogenous growth literature (Jones 1995). Agglomeration effects make the rewards for higher skills much higher in one country than in others, and they also create differences across locations within the same country. Prominent examples of agglomeration include Silicon Valley, Hollywood and Wall Street as well as professional team sports, top academic departments and research centers.

At the core of the agglomeration process is trade in services provided by high-skilled people. Continuing with the Silicon Valley example, high-tech companies compete with each other globally; their market is not limited to Northern California. Thus, there is no inherent limit as to how many firms can physically locate in Silicon Valley. On the contrary, entrepreneurs, engineers and scientists lead to employment of others like them as they start new firms or expand existing ones. They share technical knowledge and business information through their social and professional networks, which become more efficient through closer physical proximity. Furthermore, thicker local markets for skilled labor can allow specialization that helps high-tech firms improve their products and compete better globally. High-skilled immigrants allow existing engineers and managers to specialize and become more productive, creating better products for worldwide consumption. Moreover, the agglomeration of activity in a specific geographic location allows larger-scale presence of complementary specialized inputs and service providers such as legal counsels, marketing executives and investment bankers.

Another important consideration for migrants is the location of education and skill acquisition. Much of the theory-whether based on the Roy selection model or agglomeration effects - describes movements of high-skilled individuals, taking their skill levels as pre-determined prior to their migration. However, much of the true migration flow is instead first prompted by opportunities for education and skill development in destination countries. It is helpful to consider "skill" to include both unobserved abilities as well as formal education in this context, since many "eventually high-skilled immigrants" originally arrive with just their innate intelligence and motivation but few observable skills and lower education levels. They choose destinations based on the quality of available schools, the possibility of subsequently 
entering the labor market and future professional opportunities. ${ }^{16}$ Bound et al. (2015b) show how migrants from China and India can realize a large return by completing a college degree in the United States and remaining there to work afterwards. The United Kingdom (19\%), Australia (22\%) and Canada (8\%) also have significant shares of foreign students in their institutions of higher education.

Additional issues arise in return- and onward-migration that we observe in the data (for an analysis of the United States, see Artuç and Özden 2016). From a policy point of view, it is important to know how long skilled migrants remain in a destination country and the characteristics of those who eventually decide to return home or continue on to a third country. The expected length of stay upon entry can impact, for example, the effort that a migrant exerts to assimilate into the host country. The actual length of stay and life stages covered also bear sharply on how migrants impact public finances. ${ }^{17}$ At an extreme, an adult migrant who only works for a few years in a host country will typically provide more tax revenue than public services consumed. In cases where the migrant's schooling or healthcare expenses are publicly funded in the host country, high-skilled migrants might then represent a net cost to their host country.

While data for circular migration remain frustratingly limited, OECD (2008) represents an extensive effort to uniformly compile this information. This report shows that $20 \%-50 \%$ of migrants leave within five years of arrival, with some variability by country pair and time period. ${ }^{18}$ Broadly, high-skilled migrants appear more likely to leave than low-skilled migrants, but the relationship varies and is frequently non-monotonic in skill levels. ${ }^{19}$ At the very highest skill levels, return rates from the United States become substantially lower. Gaule (2014) calculates that less than $10 \%$ of foreign-born chemistry faculty in U.S. Ph.D.-granting institutions go back to their home countries, with those from China and India especially unlikely to return. Reflective of our sports examples above, the most productive chemists are also the most likely to stay in the United States.

Textbook models tend to consider migration as an individual location choice resulting from maximization of income and other personal objectives. Yet many high-skilled migration decisions have other actors involved - most notably firms that move their workers across national borders (Kerr et al. 2015a). The scale and growth of workforces within multinational firms are often underappreciated and under-explored in the migration literature. Global companies like IBM, General Electric, and Siemens usually have at least half of their workforces employed outside of their headquarter country. While unskilled workers are often drawn from the local labor markets within each country of operation, experienced high-skilled workers and especially senior managers are frequently transferred to different country offices throughout their careers. In other cases, many large high-tech companies send recruitment teams to the best engineering schools in India, China and other emerging economies. Some of the selected individuals may then migrate to the United States or Europe within the firm, as the model would predict, based upon individual decisions and relative wage differences. Observers predict that this type of migration will

\footnotetext{
${ }^{16}$ Some important papers on this interface include Rosenzweig (2006), Kato and Sparber (2013) and Grogger and Hanson $(2013,2015)$.

${ }^{17}$ For example, Storesletten (2000, 2003), Kerr and Kerr (2011), Liebig and Mo (2013), and Dustman and Frattini (2014).

18 The historical patterns agree with these numbers: more than half of the migrants who came to the United States during the "mass migration" period eventually returned home (Bandiera et al. 2013).

${ }^{19}$ For example, Pohl (2006), Dustmann and Weiss (2007), Finn (2007), Gundel and Peters (2008), Aydemir and Robinson (2008), Harvey (2009), Gibson and McKenzie (2009), Bijwaard (2010), and Bijwaard and Wahba (2014).
} 
continue in the foreseeable future since there are large cohorts (in absolute numbers) of students that are graduating in China, India and other countries (Freeman and Huang 2015).

The complete picture is even more complex and multidirectional, with top-notch talent flowing within firms in ways that no standard economic model would predict. Global companies often seek to build their presence in the largest consumer markets, and developing countries provide great potential for rapid growth. Companies send their best employees abroad to enable and lead this corporate development, paying salaries commensurate with or better than what the employee would have earned at home and definitely far in excess of what is typical in the destination country. As an example, Honeywell, a multinational conglomerate with strong roots in aerospace, uses the terminology of "high growth regions" instead of "emerging markets" to describe these overseas assignments to employees, since global opportunities account for the majority of the firm's growth. Additional factors, such as tax policies or environmental regulations, also shape the location choices of multinationals and their distributed labor demand. In multinational companies, one or more overseas assignments are common prerequisites for being promoted into the very senior leadership positions. Many global companies also require all employees to speak a common language, usually English, including Rakuten in Japan and Nokia in Finland (Neeley 2012).

In summary, the classic model of migration decisions needs to be augmented to account for the multidirectional nature of high-skilled migration and the large variations in patterns across countries. The interesting patterns are intuitively linked to the behavior of global firms, institutional and educational differences over countries, and productivity spillovers. This is especially true for superstar talent, for whom global movement and connectivity is almost a necessity for productivity. Further extensions to the basic theory and empirical work for high-skilled migration are a top priority.

\section{Policy Factors Shaping High-Skilled Migration Flows}

The demand and supply of high-skilled migrants and the resulting flows are shaped at least in part by national (migration, labor market and education) policies. High-skilled migration policies are increasingly popular tools implemented by policymakers to attract and select economic migrants. Typically, destination countries adopt one of two broad migration policy regimes (Kerr et al. 2016). Demand-driven policies require that incoming migrants must first acquire a job at the destination country. Migrants' almost-immediate employment is therefore prioritized, and potential employers and current labor market conditions play a key role in determining who is able to migrate. Supply-driven policies instead require incoming migrants to be evaluated by a points-based system, with points awarded along numerous dimensions like age, education, professional experience (or earnings), occupation, language proficiency, and so on. Some argue that supply-side policies reflect a more flexible notion of human capital and adopt a longer-term view, and Boeri et al. (2012) argue that immigration policies are only able to effectively attract and fully employ human capital if orientated toward longer-term objectives. 
Despite this extreme depiction, most countries combine elements of both approaches and implement many other policy instruments such as quotas, shortage lists, labor market tests, supplementary pointsbased tests, post-entry rights, ${ }^{20}$ policies to protect the employment of natives, financial incentives, etc. These additional elements generally aim to make an immigration destination more attractive to potential migrants while protecting domestic workers against very strong competition. Moreover, in addition to implementing certain policies (the extensive margin), countries also decide upon the stringency with which they enforce existing policies (the intensive margin). Thus, it is also far from clear whether various policy elements act in the same or opposite directions for the same individual. These inherent contradictions make comparing the efficacy of policies across countries and over time quite challenging. As such, Parsons et al. (2014) emphasize the analysis of "Policy Systems", which comprise various policy elements that need to be evaluated in tandem with one another.

While recording and measuring policies are complex, testing their effectiveness proves even more difficult. First, high-skilled migrants consider a raft of socio-economic and non-economic factors when deciding where to move. Papademetriou and Sumption (2013) term these the "immigration package," and our measurement of this mix is quite poor. Second, estimations are most useful for policy work when they tightly match the target population, but this requires detailed migrant flow data that are very difficult to assemble (Czaika and Parsons 2016, forthcoming).

Comparisons of supply and demand policy approaches should account for their differences in terms of their intended time horizons and varying definitions of human capital. Figure 7a plots incoming highskilled migrant flows to Canada between 1980 and 2012, disaggregated by duration of stay. ${ }^{21}$ While they follow a similar trend, there are certain meaningful differences that would influence the results of analyses conducted at annual frequency. Next, Figure $7 \mathrm{~b}$ plots migrants of all durations of stay and analyzes definitions of high-skilled migrants by the occupation (ISCO Categories 1-3) in contrast with education (tertiary). These series differ quite wildly given the substantial growth of migration to Canada based upon education and without a recorded occupation upon arrival.

\{Figures 7a and 7b: Canadian Immigration Structure, 1980-2012\}

Another important issue is the point in time at which migration actually occurs. It is somewhat natural to think that migrant inflows in a given year imply arrival of migrants across a country's border in that year. However, the timeline might be far from clear since many migrants change their legal status while they are in the country without actually moving and they are interpreted as new arrivals in the administrative records. This distinction is highlighted for the United States in Figure 8a by plotting the annual rates of new arrivals and those "adjusting status" for those obtaining permanent residence as they exit from their visa status. Figure 8b similarly considers the data for the United Kingdom. Those from outside of the United Kingdom are recorded as having received work permits, while those individuals that transferred to employment status are deemed to have been granted first permission to work. These figures show that high-skilled migrants enter the labor market through very different channels in the two countries. The

\footnotetext{
${ }^{20}$ For example, provisions for family reunification and spouses' rights to employment and permanent residence.

${ }^{21}$ A migrant in this analysis is deemed high-skilled if he or she is working in an occupation that falls into the first three categories of the International Standard Classification of Occupations (ISCO): (1) Managers, senior officials and legislators, (2) Professionals and (3) Technicians and associate professionals.
} 
United States experiences greater numbers of high-skilled migrants obtaining permanent resident status through adjustments after having arrived previously on a temporary or a student visa. By contrast, most high-skilled labor migrants to the United Kingdom arrive with direct work permits from abroad and are subject to greater initial screening.

\{Figures 8a and 8b: Arrivals and Adjustments in United States and United Kingdom\}

Given these complications, it is perhaps not surprising that studies evaluating the effectiveness of highskilled migration policies are sparse (Rinne 2013). Early studies on the topic typically examined single destination countries. Green and Green (1995) in the case of Canada, for example, conclude that changes in the points-based system introduced in 1967 influenced the occupational composition of incoming migrants. Miller (1999) examines the Australian policy system and argues that unemployment rate differentials across migration categories reflect migrant characteristics as opposed to their entry channel. Cobb-Clark (2003), also in the case of Australia, finds that immigrants facing more stringent entrance criteria fared significantly better in terms of their labor market integration. Antecol et al. (2013), while analyzing the immigration policies of Australia, Canada and the United States, argue that the relatively low average skill level of migrants to the United States is largely driven by the geographic and historic proximity of Mexico, as opposed to differences in immigration policy. In more recent years, the literature has tended to examine the effect of high-skilled migration on particular outcomes by utilizing changes in high-skilled policies as an identification strategy (e.g., Kerr and Lincoln 2010) as opposed to testing the efficacy of policy in meeting its stated objectives.

To facilitate better comparisons across countries and more systematic assessments, large-scale projects seek to build global databases of high-skilled migration policies. DEMIG POLICY database (de Haas et al. 2016) extends the methodology of Mayda (2010) to codify 6,500 migration policy changes made by some 45 countries during 1900-2014. An important feature is that absolute levels of policy criteria are not recorded, only policy changes, and the degree to which they are more restrictive, neutral, or less restrictive are detailed. The degree and stringency to which policies have been enacted are unknown. Nevertheless, a number of additional dimensions have been added to flesh out more detail, including the level of legislation, the level of policy change, policy area, policy tool, and details on the specific target population. The DEMIG POLICY database proves particularly useful for high-skilled migration research since it separately identifies policies aimed specifically at high-skilled migrant flows. Figure 9 depicts the average net weighted change in policy stance towards high-skilled migrants over the period 1990-2013. All of the net changes are negative, indicating that the policy stance of OECD members has become ever more relaxed toward high-skilled migration in every year since 1990.

\{Figure 9: Permissiveness of OECD High-Skilled Migration Policies, 1990-2013\}

In a companion project, Czaika and Parsons (2016, forthcoming) construct a dataset of a series of variables for 19 OECD countries which have put 15 specific policies in place during 2000-2012. This approach allows greater scope for analysis of within and between variations, although they do not measure the intensity of enforcement. Czaika and Parsons (2015) find that supply-driven systems prove more effective in increasing the absolute numbers of high-skilled migrants and the skill composition of incoming cohorts. 
Also in development are two additional databases that use new approaches: the International Law and Policy Analysis (IMPALA) database (Gest et al. 2014, Beine et al. 2014, 2015) and the Immigration Policies in Comparison (IMPIC) database (Bjerre et al. 2014). The construction of IMPALA is guided by legal experts who deconstruct immigration policies at the national level from legal texts (i.e., de jure rules) into hundreds of binary or categorical variables. Their main units of analysis are the entry paths family reunification, high-skilled policies, lotteries, asylum, etc. Similar to Czaika and Parsons (2015), these binary variables can be variously aggregated up to form indices that embed dimensions of interest. To date, nine countries are included in IMPALA and cover the period 1999-2008. The IMPIC database also draws upon country legal experts to code specific levels of restrictiveness in each country and year that range from zero to one. The project aims to collect data for 33 OECD countries between 1980 and 2010. One particular advantage of these two databases is that the intensive and extensive margins of policies can be evaluated simultaneously, which has the potential to dramatically shift forward our understanding of the role of migration policies.

As noted earlier, a crucial and frequently overlooked aspect of the current literature is the fact that a highskilled worker can arrive through channels quite separate from the simple labor channels emphasized by theory (either exogenously or endogenously). Reliable and detailed administrative data that facilitate analyses of high-skilled workers arriving through non-economic channels are difficult to access. Australian data for example, separates four main channels: a skill channel for those that enter Australia for the primary purpose of work; a family channel; a humanitarian channel; and a non-program channel that comprises those that had previously resided in Australia without having obtained permanent settlement. Figure 10a shows an intuitive ordering in which the proportion of high-skilled migration is highest for the skill channel and lowest for those entering Australia for humanitarian reasons, but the differences are not that large. Figure 10b shows at least one-third of high-skilled migrants since the late 1990s have entered Australia through a "back door" channel other than the skill channel. In a similar spirit, Hunt (2011) shows that high-skilled migrants enter the United States through a variety of visa categories and that these differences are connected to subsequent performance, especially on innovative and entrepreneurial outcomes. There is every reason to suspect this phenomenon is widespread across all destination countries, and researchers need to look more closely at its implications for studies of single programs or channels and in aggregate.

\{Figures 10a and 10b: Human Capital through the Back Door in Australia\}

Noticeably, there are few effective or extensive bilateral or regional agreements on migration workers, and it has been frequently noted that there is no "World Migration Organization" to govern global mobility regimes, unlike the World Trade Organization for trade policy. Instead, we have a complex dance of countries taking unilateral actions and some bilateral or regional arrangements emerging along the way. Research needs to move from a narrow focus on one country or channel to a multi-channel perspective for a single country or a multi-country perspective in a global setting. The trade literature, for example, has developed substantially around the Eaton and Kortum (2002) model that allows for depictions of global Ricardian trade. The European Union offers a live case study that should be closely analyzed in years to come, after it has opened the doors for internal migrant flows and curtailed gatekeeping by individual countries (only to have some doors potentially closed by Brexit). 
Coming from the opposite direction of this call for global analysis, and hopefully meeting in the middle, is a greater need to consider the role of institutions such as firms and universities in shaping immigration policies and patterns. This is especially true in countries like the United States, which use demand-driven systems like the H-1B visa program for high-skilled migration. Rather than the migrants submitting applications to enter, the firms sponsor the H-1B visa applicants and make the applications, indicating that a firm-worker match is already in place. This worker could be a professional residing abroad, a foreign student graduating from a U.S. university, a current employee of the firm abroad or many other variants. There is relatively little screening of the visa applications beyond basic requirements for the worker and work conditions, and visas are allocated on a first-come, first-served basis up to an annual cap. A lottery is employed in years when demand outstrips supply almost immediately, which is true in robust economic times like 2016. The regulated and capped supply lacks a pricing mechanism, and no limits are placed by occupation, sector or nationality. Upon arrival to the United States for work, the highskilled migrant is effectively tied to the sponsoring firm until he or she obtains permanent residency or a temporary visa sponsored by another firm. The firm can potentially sponsor the employee for a green card, a process that takes six years (or longer for some nationalities), during which time the employee is even more closely tied to the firm, creating a modern version of indentured servitude in some cases. Kerr et al. (2016) provide greater details and comparisons with points-based approaches.

Given this setting, Kerr et al. (2015a,b) stress that research in the United States and similar demanddriven systems needs to take greater account of the firm. This is especially the case for multinational firms that employ larger number of migrants and make global sourcing and production decisions. This approach can be a significant departure from models that are built on a conceptual lens of individual actions (e.g., a competitive labor market analysis for measuring employment effects, the Roy model of migration selection). Such models tend to push the firm into the background (e.g., providing a fixed demand curve for workers), whereas the reality is very different. Put starkly, rather than high-skilled migration decisions being about generating the greatest individual gains, as is implicit in the earlier model, they can become about the greatest firm-level gains. These may be correlated, but the mapping is far from one-to-one. Moreover, differences in migration policy across countries may impact firm structures and global business competition.

In a policy framework where the economic motivations of firms take center stage, research needs to carefully consider how to adapt the standard techniques and empirical models developed for other labor market analyses. It is very important to understand how visas are used within the sponsoring firms, and how the global and local business models of firms can be shaped given the constraints of the policy environment. As an illustration, many $\mathrm{H}-1 \mathrm{~B}$ visas are issued to Indian outsourcing companies bringing their employees to the United States to help with the outsourcing process. This was not the original intent of the program, and it is one of many examples where the motivations of policies meet the practicalities of decentralized implementation by profit-maximizing economic agents. ${ }^{22}$

\footnotetext{
${ }^{22}$ Along these same lines, colleges and universities play a very important role in shaping the future U.S. high-skilled migration pool and labor market through their admissions decisions. The incentives of these institutions can also be different from those originally anticipated by policy makers. For example, public institutions with tight or underfunded budgets can find foreign students very attractive due to the higher tuition rates that they pay. Moreover, institutions in remote and declining areas of the country may become very reliant on overseas students seeking to
} 
Data advances are aiding our understanding of this process in two important ways. First, the development of employer-employee datasets in many countries allows us to look inside the firms, as many of these databases record the nationality or immigration status of the worker. Kerr et al. $(2015 \mathrm{a}, \mathrm{b})$ consider the Longitudinal Employer-Household Dynamics database for the United States. Beyond providing microdata, this line of research allows us to gain new perspectives that take into account the economic incentives of the firm. Kerr et al. (2015b), for example, quantify the extent to which employers use the visa program to keep their U.S.-based workforces younger in order to take advantage of lower wage rates, fewer family commitments, and so on. Opponents of the H-1B program have argued strongly about this age dynamic (Matloff 2003), but it is not feasible to study it using classic labor economics approaches from perspectives that omit firms. Data that facilitate firm perspectives offer substantial promise, similar to the transformation of international trade over the past decade as the role of the firm took center stage. This will be especially true when integrated data begin to afford employee-level records for multinationals in many countries, rather than analysis being restricted to the administrative data of a single country.

Data are also helping to identify the role of firms in the lobbying process for migration policy. Given the importance of high-skilled migrants for their success, it is not surprising that firms attempt to shape the admissions process. Kerr et al. (2014) examine the lobbying efforts of U.S. public firms for high-skilled migration, building upon the interest group work of Facchini et al. (2011) for broader immigration policies. Public disclosure in the United States now requires firms to publicly release all of their lobbying activity to the government and the issues on which they are engaged. This literature is very thin, especially relative to its importance, yet surprising results emerge. For example, Kerr et al. (2014) document that much of the U.S. lobbying on high-skilled migration is done by firms that regularly lobby on many issues, which only partially overlap with the firms that are most dependent upon the migration policy outcomes. Going forward, we anticipate additional lines of inquiry to refine these politicaleconomy aspects of migration policy.

\section{Economic Implications of High-Skilled Migration Flows}

The implications of global talent flows are profound, with the power to influence all aspects of our professional and social lives. Freeman (2013) describes global knowledge as the "ring to rule them all." This review cannot cover every topic, and so we continue by isolating themes connected to our conceptual focus on agglomeration economies and workplace outcomes. We also continue to focus upon areas where new data and methodological advances will unlock our ability to analyze important questions. Hanson et al. (2016) connect talent flows to frontier research in neighboring fields of international economics.

Not surprisingly, labor market consequences of high-skilled migration for natives in receiving countries are significant themes of recent research (Docquier et al. 2014). This is important for policy makers, and the observed wage and employment dynamics provide direct evidence on the strength of agglomeration

enter the United States for education and employment. Policy makers rarely anticipate all of these unintended approaches and gamesmanship when setting up policy structures. 
economies. This line of work has been also tightly connected with measuring the patenting, innovation, and entrepreneurial outcomes of migrants given the higher concentration of these inflows in STEM fields. ${ }^{23}$ Indeed, many policy arguments have at their heart questions on whether high-skilled migrants generate or take away jobs and whether they expand technology frontiers to push growth.

Kerr (2016) describes the quantity and quality of U.S. high-skilled immigration and reviews the nuanced results in this literature. In short, studies that look at variations across cities and regions tend to find results very consistent with agglomeration economies, quantifying how high-skilled migrants boost innovation and productivity outcomes. These studies also rarely find adverse wage and employment consequences, and longer time horizons tend to show greater gains. ${ }^{24}$ This line of research has been mostly focused on the United States, which ceteris paribus gives the most appropriate test of the agglomeration hypothesis given its dominant position as a destination country for high-skilled migration inflows (as noted in Section 3) and its large size. Still, positive net impacts of national diversity on innovation are observed in several European countries. ${ }^{25}$ Further research has confirmed the productivity differences across places for the same high-skilled individuals using rigorous methods (e.g., Clemens 2013, Kahn and MacGarvie 2016).

There are, however, some disagreements on the overall positive effects of high-skilled immigration on native workers. First, several studies with an occupational focus, especially for computer scientists and mathematicians, find large enough displacement effects such that high-skilled migrants yield zero net benefit. ${ }^{26}$ There is also evidence that displacement may occur among students. ${ }^{27}$ Academic settings often have restrictions that prevent agglomeration economies, such as the fixed size of academic mathematics departments described in Borjas and Doran (2012) or caps on the numbers of majors in a college department. Doran et al. (2014) further provide recent evidence with H-1B visa lotteries that the marginal visa may not provide benefits that other studies anticipate.

We anticipate new data to further this work along several avenues of enquiry. First, following Peri and Sparber (2011), a significant theme of recent research is how field and occupation selection of highskilled migrants can complement native workers. Data on occupations, especially at the firm level, can provide insights on the degree to which immigrants specialize in particular occupations (e.g., engineering) that port well globally and then complement natives focusing on other occupations (e.g., law, marketing) that require more local context and familiarity. Kerr et al. (2016) describe the deep challenges that emerge when interpreting this work, but a first-order effort needs to focus on building our fact base. Second, the linking of employment records to patents and similar innovation datasets offers untapped capabilities to study where agglomeration economies exist and how they function (e.g., citations among inventors, recombinations of technologies).

\footnotetext{
${ }^{23}$ Carlino and Kerr (2015) review the fundamental connections between agglomeration economies and innovation.

${ }^{24}$ For example, Hunt and Gauthier-Loiselle (2010), Kerr and Lincoln (2010), Lofstrom and Hayes (2011), Stuen et al. (2012), Moser et al. (2014), Kerr et al. (2015b), Peri et al. (2015), and Ghosh et al. (2016).

${ }^{25}$ For example, Ozgen et al. (2011), Parrotta et al. (2013), Bosetti et al. (2013), Breschi et al. (2014, 2015), and Nathan (2015).

${ }^{26}$ For example, Matloff (2003), Hira (2010), Borjas and Doran (2012), and Bound et al. (2015a).

${ }^{27}$ For example, Borjas (2005, 2006), Lowell and Salzman (2007), and Orrenius and Zavodny (2015).
} 
Turning our attention to origin countries, research evidence is accumulating. Much of the early work in this literature centers on the "brain drain" hypothesis, where the migration of talented individuals to highincome countries strongly disadvantages the source (mostly lower-income) country due to loss of tax dollars, complementary skills, business leaders, role models, providers of public services and so forth. There are certainly cases of extreme brain drain, where some African countries suffer from a severe lack of medical doctors. The overall welfare calculation becomes more complex, however, in many settings when we consider ways that diasporas can generate gains for their home countries. For example, globally connected migrants can aid economic and non-economic exchanges that include trade and foreign direct investment (FDI), technology and knowledge, cultural norms and political views (e.g., Parsons and Winters 2015).

Several studies find that high-skilled migrants to the United States provide technological and business benefits to their countries of origin. Surveys of immigrant scientists and engineers in Silicon Valley undertaken by Saxenian et al. (2002) are quite well-known and provocative in this regard. While such results must be treated with heavy caution given the highly selected nature and narrow focus of the survey sample, this study finds about half of high-skilled migrants engage in business exchanges with their home countries annually or with greater frequency. The survey further suggests that more than $80 \%$ of highskilled migrants share technical information. Since the publication of the Saxenian et al. (2002) study, and in part because of it, the literature increasingly centers on "brain gain" possibilities from high-skilled migration for sending countries. ${ }^{28}$

Subsequent academic work seeks to assemble data for more rigorous quantification. One route uses patent data and inventor citations to measure heightened knowledge flows across countries, where migration to the United States pushes forward technology development abroad, similar to the technology transfer literature (Keller 2004). This work emphasizes the special access that high-skilled migrants can provide to very recent innovations that boost productivity abroad (Kerr 2008), and Kerr (2013) shows that the accumulated transfers are significant enough to influence the exports of home countries. Agrawal et al. (2011) find that knowledge diffusion from the Indian diaspora in the United States aids the development of major advances in India more than domestic inventors in India, but the opposite is true for the development of incremental inventions. There is substantial heterogeneity in the strength of these connections and the types of transfers facilitated (Oettl and Agrawal 2008, Kerr 2008).

Studies also connect migrants to their home countries through formal business channels like FDI (e.g., Kugler and Rapoport 2007, 2011, Javorcik et al. 2011, Kim and Park 2013), with Docquier and Lodigiani (2010) specifically focusing on skills and business networks. Foley and Kerr (2013) examine firm-level data from the Bureau of Economic Analysis connected to ethnic patenting data. Their work emphasizes how high-skilled migrants can enable their U.S. employers to conduct R\&D-based work abroad and navigate overseas environments without the aid of joint venture partners. ${ }^{29}$ Recent work further emphasizes the role of global collaborative teams for innovation (e.g., Miguelez 2014, Branstetter et al.

\footnotetext{
${ }^{28}$ Docquier and Rapoport (2012) provide an extended review of the brain drain and brain gain literatures, related theory, and comprehensive empirics.

${ }^{29}$ Research also considers migration and trade (e.g., Rauch 2001, Rauch and Trindade 2002), with Hatzigeorgiou and Lodefalk (2011) being an example of firm-level analysis. The specific relationship of high-skilled migration to trade is less developed.
} 
2015, Kerr and Kerr 2015). This research strand has a promising future given the increasing presence of global inventor teams, which Kerr and Kerr (2015) estimate rose from 1\% of U.S. public company patents in 1982 to $6 \%$ in 2004, and due to the impressive amount of information that patent records contain and our developing databases for innovations worldwide.

One area that requires close attention is the role of high-skilled migrants in the overseas outsourcing of work. High-skilled Indian migrants are thought to play an important role in India's outsourcing industry and the phenomena is likely to be much broader. Hira (2010) decries how Indian firms use the U.S. H-1B program as a vehicle for outsourcing, which we noted earlier is not the program's intent but allowed by the program's legal structure. In 2013, for example, the top three applicants for H-1B visas were Indian outsourcing firms, with Infosys (ranked \#1) applying for three times more visas than Microsoft (\#6). This is in line with earlier work that notes (usually from a more positive perspective) how diasporas can provide information about economic opportunities to their home countries and serve as reputational intermediaries. Even in online labor-sourcing platforms, Ghani et al. (2013) find evidence of U.S.-based ethnic Indians being more likely to send work to India when outsourcing tasks. But, overall, little is really known about this, and the theory of trade in tasks is quite nuanced (Grossman and Rossi-Hansberg 2008). Given the ongoing polarization of the labor markets in the United States and other advanced economies, this is a very important gap in the literature.

A growing body of research quantifies how high-skilled migrants continue to interact with their home countries after moving to advanced economies. This is only one aspect of the brain drain vs. brain gain debate (e.g., Agrawal et al. 2011, Weinberg 2011, Docquier and Rapoport 2012) and each country and circumstance is ultimately unique. To complement, two other research gaps are worth stressing. First, the circular flow of talent over short and long durations is increasingly emphasized as "brain circulation" (e.g., Saxenian 2006, Nanda and Khanna 2010, Hovhannisyan and Keller 2015). Reflecting the data challenges mentioned before on the varieties of migration pathways into countries and their associated durations of stay, the literature has very little to say about the respective economic impacts of short-term and transit migration compared to longer and permanent stays. Second, cost-benefit analyses should factor in where migrating individuals are trained, who funds the training, and what other opportunities exist (e.g., Bhagwati 1976, Beine et al. 2009, Özden and Phillips 2015). In other words, the counterfactual of high-skilled migration is difficult to set, and it may be that "high-skilled" only comes with "migrant" in an important number of settings.

These discussions naturally lead to a key objective that research should address over the next decade, namely, to trace out how high-skilled migration impacts inequality within and across countries. When discussing key policy considerations and data development above, we reflected on the simultaneous need for both a more global/macro perspective that embodies many countries and also a more micro-data perspective of certain understudied but pivotal actors. The same holds on the inequality front. On one level, we need to begin the effort to say how high-skilled migration impacts global inequality, going beyond the labor market impacts in receiving economies and the brain drain/gain role in sending economies. With agglomeration economies in advanced economies for innovation and global competition and spillovers over countries, it could well be that the impact on third-party countries is quite profound. For example, the migration of talent to the United States from India is likely to have a non-trivial role in the competition among multi-national firms in the electronics industry, which may then impact Japan through product market competition and China through production contracts. Many of Apple's and 
Google's high-skilled workers are migrants, and thus the travails of Nokia in Finland may be partly attributable to the special clustering in Silicon Valley that high-skilled migration facilitates.

Second, to understand the impact of high-skilled migration for inequality, we need to understand the real distribution of returns. This task is again quite complex and requires extensive micro-data work. One aspect is the location of production and other inputs (e.g., finance, marketing) that surround the work of high-skilled migrants, which are often drawn from far-flung locations. Furthermore, even within one city, our economic models point towards a focus on real income levels that are net of prices. The standard spatial equilibrium models from urban economics would suggest that landlords and property owners in the core clusters would reap enormous benefits (Glaeser 2008), and the skyrocketing rental rates and property prices in Silicon Valley, London, etc. suggest this holds true. Many highly paid individuals in these clusters say they can never afford a home! Saiz (2007) connects immigration to rising American rents, and this has been observed in other settings too. This may indicate that the battery of studies that find no labor market displacement due to migration miss important declines in real wages once prices are considered; accounting for the role of city amenities, property prices, and so forth is very complex but should be done. In the end, agglomeration economies revolve around trade-offs, as the escalating demand for the productivity benefits of being located in a hot spot are weighed against the escalating costs. We anticipate the research going forward to be better able to capture these features and enhance our understanding.

\section{Looking Forward}

In some respects, research into high-skilled migration has a lot to be proud of over the last decade, with the emergence of new datasets, rapidly increasing visibility in leading journals and more young researchers entering the field. Part of this review has been to bring together these various streams of effort and celebrate the progress made. We have a significantly larger number and variety of data sources than before, and new ones are in the pipeline. Research on high-skilled migration has also begun to develop its own conceptual voice, distinguishing itself from traditional immigration analyses. As the welfare and policy implications of high-skilled migration are quite different from low-skilled migration, ranging from the role of sponsoring firms to agglomeration economies, this too is very promising. On the other hand, one can't help but feel that the progress made in other areas of international economics like international trade or finance was even greater during the last decade. We hope that this field is at the cusp of a similarly transformative decade.

We close this review by continuing our strong emphasis on data and describing productive areas for data construction that have not already been mentioned. First, much more research remains to be done to fully understand the contribution of high-skilled immigration to economic growth and development in both origin and destination countries, especially as creators and transmitters of knowledge. As such, we need to better unite high-skilled migration data together with productivity data at the firm and sector levels. Many countries collect data on work visas, entry permits, permanent residency and citizenships that are awarded to high-skilled migrants, but these data are rarely merged together with the employer-employee datasets or labor force surveys that underlie economic research for productivity outcomes. Often the reason is simply that different authorities maintain the databases, and researchers have no way to bring the 
elements together. This is partly due to legitimate privacy and data security concerns, but we believe it is possible to overcome these barriers, for example, by utilizing the government research data centers that are increasingly available in many countries or using data matching techniques (Özden and Phillips 2015). Reducing these obstacles would aid research on how globally mobile talent pushes the technological frontier forward, where spillovers to domestic workers are most effective, and so on. Without detailed information on immigration visas and pathways and the ability to match them to labor market and productivity data, our policy recommendations will always be incomplete.

Second, we need to improve upon how we measure skills and migration, which rely too much on recorded education and place of birth, respectively. We know university degrees obtained in different locations do not indicate the same quality or type of human capital, yet we treat them as equivalents in our empirical analysis. Related to this issue, how can we better measure the mobility of raw human capital through enrollment in schools, on to first jobs, and then on to careers as celebrated scientists or CEOs? This seems particularly relevant for settings like Europe where high-skilled individuals frequently live in multiple countries for study and work over their careers, with evolving human capital at each stage. The (partially endogenous) shape of this development path impacts the implications of borders, the fiscal consequences for public finances over countries, and how domestic and multi-national firms operate. Some part of this can come through accessing data from the personnel records of multinational corporations (e.g., Choudhury 2016), with integrated datasets being the long-term goal. The development of electronic visas is particularly promising for future data assembly efforts. We also need to build better data on the families of high-skilled migrants, about which we know very little, to study their outcomes and impacts on others (e.g., spillovers among children within schools).

These last two paragraphs are mostly cast in terms of developing administrative datasets, and we do believe this is critical. In parallel, of course, is the enormous rise of potential sources of information through online platforms like Facebook and LinkedIn. This potential includes the obvious (e.g., networks, occupation and professional titles, skills) and the more subtle (e.g., the Internet Protocol addresses of host computers can be linked to latitude-longitude coordinates to provide unprecedented detail on location). It is quite fortuitous that high-skilled individuals are major users of these digital platforms. Public availability of patent data is one reason why this part of the high-skilled migration literature is much further developed than equally important spheres of work. We don't know where these other roads will lead, but we are eager to find out!

Global integration is generating ever-greater returns for matching the right talent with the right job or opportunity, with country borders being relegated to second-order in importance... except that these borders are far from that! Intricate national migration policies, and the gatekeepers that the policies establish, still hold sway. Moreover, many points of resistance emerge, due to knee-jerk political reactions alongside well-placed concerns about implications for domestic workers. Economists should be cautious about over-reliance on tidy models, as political realities and messy business deals play powerful and complex roles that we are only starting to understand. The most successful individuals, companies, and countries will be those who discern how to best navigate the current web and how to untangle its knots to discover a better potential as we move forward. 


\section{References}

Agrawal, Ajay, Devesh Kapur, John McHale, and Alexander Oettl, "Brain Drain or Brain Bank? The Impact of Skilled Emigration on Poor-Country Innovation", Journal of Urban Economics 69 (2011), 43-55.

Akcigit, Ufuk, Salome Baslandze, and Stefanie Stantcheva, "Taxation and the International Migration of Inventors", American Economic Review 106:10 (2016), 2930-2981.

Alesina, Alberto, Johann Harnoss, and Hillel Rapoport, "Birthplace Diversity and Economic Growth", Journal of Economic Growth 21:101 (2016), 101-138.

Anderson, Stuart, "The Importance of International Students to America", National Foundation for American Policy Brief (2013).

Antecol, Heather, Deborah A. Cobb-Clark, and Stephen J. Trejo, "Immigration Policy and the Skills of Immigrants to Australia, Canada, and the United States", Journal of Human Resources 38:1 (2003), 192-218.

Arslan, Cansin, Jean-Christophe Dumont, Zovanga Kone, Yasser Moullan, Çaglar Özden, Christopher Parsons, and Theodora Xenogiani, "A New Profile of Migrants in the Aftermath of the Recent Economic Crisis", OECD Social, Employment and Migration Working Paper 160 (2014).

Artuç, Erhan, Frederic Docquier, Çaglar Özden, and Christopher Parsons, "A Global Assessment of Human Capital Mobility: The Role of non-OECD Destinations", World Development (2015).

Artuç, Erhan, and Çaglar Özden, "Transit Migration: All Roads Lead to the United States", Working Paper (2016).

Aydemir, Abdurrahman, and Chris Robinson, "Global Labor Markets, Return and Onward Migration”, Canadian Journal of Economics 41:4 (2008), 1285-1311.

Bandiera, Oriana, Imran Rasul, and Martina Viarengo, "The Making of Modern America: Migratory Flows in the Age of Mass Migration", UCL Working Paper (2013).

Barro, Robert, and Jong-Wha Lee, "A New Data Set of Educational Attainment in the World, 19502010”, Journal of Development Economics 104 (2013), 184-198.

Beine, Michel, Frédéric Docquier, and Hillel Rapoport, "Measuring International Skilled Migration: A New Database Controlling for Age of Entry", World Bank Economic Review 21:2 (2007), 249254.

Beine, Michel, Anna Boucher, Brian Burgoon, Mary Crock, Justin Gest, Michael Hiscox, Patrick McGovern, Hillel Rapoport, Joep Schaper, and Eiko Thielemann, "Measuring Immigration Policies: Preliminary Evidence from IMPALA", CESifo Economic Studies 61 (2015).

Beine, Michel, Anna Boucher, Brian Burgoon, Mary Crock, Justin Gest, Michael Hiscox, Patrick McGovern, Hillel Rapoport, Joep Schaper, and Eiko Thielemann, "Comparing Immigration Policies: An Overview from the IMPALA Database", International Migration Review (2015).

Bhagwati, Jagdish, "Taxing the Brain Drain", Challenge 19:3 (1976), 34-48.

Bhargava, Alok, Frédéric Docquier, and Yasser Moullan, "Modeling the effect of Physician Emigration on Human Development", Economics and Human Biology 2:9 (2011), 172-183.

Bijwaard, Govert, "Immigrant Migration Dynamics Model for the Netherlands", Journal of Population Economics 23 (2010), 1213-1247.

Bijwaard, Govert, Christian Schluter, and Jackline Wahba, "The Impact of Labor Market Dynamics on the Return-Migration of Immigrants", Review of Economics and Statistics 96 (2014), 483-494.

Bijwaard, Govert, and Jackline Wahba, "Do High or Low Income Immigrants Leave Faster?", Journal of Development Economics 108 (2014), 54-68.

Bjerre, Liv, Marc Helbling, Friederike Römer, and Malisa Zobel, "Conceptualizing and Measuring Immigration Policies: A Comparative Perspective”, International Migration Review 49:3 (2014), 555-600.

Boeri, Tito, Herbert Brücker, Frédéric Docquier, and Hillel Rapoport (eds.), Brain Drain and Brain Gain: The Global Competition to Attract High-Skilled Migrants (Oxford: Oxford University Press, 2012). 
Borjas, George, "Self-Selection and the Earnings of Immigrants", American Economic Review 77 (1987), 531-553.

Borjas, George, "Immigrants in the U.S. Labor Market: 1940-80", American Economic Review 81:2 (1991), 287-291.

Borjas, George, "Do Foreign Students Crowd Out Native Students from Graduate Programs?", in Ronald Ehrenberg and Paula Stephan (eds.), Science and the University (Madison, WI: University of Wisconsin Press, 2005).

Borjas, George, "Immigration in High-Skill Labor Markets: The Impact of Foreign Students on the Earnings of Doctorates", NBER Working Paper 12085 (2006).

Borjas, George, Labor Economics. 4th ed. (Boston, MA: McGraw-Hill/Irwin, 2008).

Borjas, George, and Kirk Doran, "The Collapse of the Soviet Union and the Productivity of American Mathematicians", Quarterly Journal of Economics 127:3 (2012), 1143-1203.

Bosetti, Valentina, Cristina Cattaneo, and Elena Verdolini, "Migration of Skilled Workers and Innovation: A European Perspective", Working Paper (2013).

Bound, John, Breno Braga, Joseph Golden, and Gaurav Khanna, "Recruitment of Foreigners in the Market for Computer Scientists in the United States", Journal of Labor Economics 33:S1 (2015a), S187-S223.

Bound, John, Murat Demirci, Gaurav Khanna, and Sarah Turner, "Finishing Degrees and Finding Jobs: US Higher Education and the Flow of Foreign IT Workers", Innovation Policy and the Economy 15:1 (2015b), 27-72.

Branstetter, Lee, Guangwei Li, and Francisco Veloso, "The Rise of International Co-invention", in Adam Jaffe and Benjamin Jones (eds.) The Changing Frontier: Rethinking Science and Innovation Policy (Chicago, IL: University of Chicago Press, 2015), 135-168.

Breschi, Stefano, Francesco Lissoni, and Ernest Miguelez, "Foreign Inventors in the US: Testing for Diaspora and Brain Gain Effects", Working Paper (2015).

Breschi, Stefano, Francesco Lissoni, and Gianluca Tarasconi, "Inventor Data for Research on Migration and Innovation: A Survey and a Pilot”, WIPO Economic Research Working Paper 17 (2014).

Carlino, Gerald, and William Kerr, "Agglomeration and Innovation", in Gilles Duranton, J. Vernon Henderson, and William Strange (eds.) Handbook of Regional and Urban Economics Volume 5 (Elsevier, 2015), 349-404.

Chiquiar, Daniel, and Gordon Hanson, "International Migration, Self-Selection, and the Distribution of Wages: Evidence from Mexico and the United States", Journal of Political Economy 113:2 (2005), 239-281.

Choudhury, Prithwiraj, "Return Migration and Geography of Innovation in MNEs: A Natural Experiment of On-the-job Learning of Knowledge Production by Local Workers Reporting to Return Migrants", Journal of Economic Geography 16:3 (2016), 585-610.

Clemens, Michael, "Economics and Emigration: Trillion-Dollar Bills on the Sidewalk?", Journal of Economic Perspectives 25:3 (2011), 83-106.

Clemens, Michael, "Why Do Programmers Earn More in Houston than Hyderabad? Evidence from Randomized Processing of U.S. Visas", American Economic Review Papers \& Proceedings 103:3 (2013), 198-202.

Clemens, Michael, and Gunilla Pettersson, "New Data on African Health Professionals Abroad", Human Resources for Health 6:1 (2008).

Cobb-Clark, Deborah A., "Public Policy and the Labor Market Adjustment of New Immigrants to Australia", Journal of Population Economics 16:4 (2003), 655-681.

Czaika, Mathias, and Christopher Parsons, "The Gravity of High-Skilled Migration Policies", Demography, (forthcoming)

Czaika, Mathias, and Christopher Parsons, "High Skilled Migration in Times of Global Economic Crisis", International Migration Institute Working Paper Series 126 (2016).

Czaika, Mathias, and Sorana Toma, "Path-Dependency in International Academic Careers", International Migration Institute Working Paper Series 108 (2015). 
Dao, Thu Hien, Frédéric Docquier, Christopher Parsons, and Giovanni Peri, "Migration and Development: Dissecting the Anatomy of the Mobility Transition", Working Paper (2016).

de Haas, Hein, Katharina Natter, and Simona Vezzoli, "Growing Restrictiveness or Changing Selection? The Nature and Evolution of Migration Policies", International Migration Review (2016), 1-44.

del Carpio, Ximena, Mohamed Marouani, Çaglar Özden, Mauro Testaverde, and Mathis Wagner, "Foreign Workers in Malaysia: Labor Market and Firm Level Analysis", Malaysian Journal of Economic Studies (2015).

Docquier, Frédéric, Lindsay Lowell, and Abdeslam Marfouk, "A Gendered Assessment of Highly Skilled Emigration", Population and Development Review 35:2 (2009), 297-322.

Docquier, Frédéric, and Elisabetta Lodigiani, "Skilled Migration and Business Networks", Open Economies Review 21:4 (2010), 565-588.

Docquier, Frédéric, and Abdeslam Marfouk, "International Migration by Educational Attainment (19902000): Release 1.1", in Çaglar Özden and Maurice Schiff (eds.) International Migration, Remittances and Development (New York: Palgrave Macmillan, 2006).

Docquier, Frédéric, Çaglar Özden, and Giovanni Peri, "The Labor Market Effects of Immigration and Emigration in OECD Countries", The Economic Journal 124:579 (2014), 1106-1145.

Docquier, Frédéric, and Hillel Rapoport, "Globalization, Brain Drain, and Development", Journal of Economic Literature 50:3 (2012), 681-730.

Doran, Kirk, Alexander Gelber, and Adam Isen, "The Effects of High-skilled Immigration Policy on Firms: Evidence from Visa Lotteries", NBER Working Paper 20668 (2014).

Dumont, Jean-Christophe, and Georges Lemaître, "Counting Immigrants and Expatriates in OECD Countries", OECD Economic Studies 3:1 (2005), 49-83.

Dumont, Jean-Christophe, John P. Martin, and Gilles Spielvogel, "Women on the Move: The Neglected Gender Dimension of the Brain Drain”, IZA Discussion Paper 2920 (2007).

Dumont, Jean-Christophe, Gilles Spielvogel, and Sarah Widmaier, "International Migrants in Developed, Emerging and Developing Countries: An Extended Profile", OECD Social, Employment and Migration Working Paper 114 (2010).

Dustmann, Christian, and Riccardo Faini, "Return Migration: The European Experience", Economic Policy 11:22 (1996), 213-250.

Dustmann, Christian, and Tommaso Frattini, “The Fiscal Impacts of Immigration into the UK”, Economic Journal 124 (2014), F593-F643.

Dustmann, Christian, and Yoram Weiss, "Return Migration: Theory and Empirical Evidence from the UK”, British Journal of Industrial Relations 45:2 (2007), 236-256.

Eaton, Jonathan, and Samuel Kortum, "Technology, Geography, and Trade”, Econometrica 70:5 (2002), 1741-1779.

Facchini, Giovanni, Anna Maria Mayda, and Prachi Mishra, "Do Interest Groups Affect U.S. Immigration Policy?", Journal of International Economics 85:1 (2011), 114-128.

Fairlie, Robert, and Magnus Lofstrom, "Immigration and Entrepreneurship", in Barry Chiswick and Paul Miller (eds.) Handbook on the Economics of International Migration (Elsevier, 2014).

Falkner, Ronald, "The International Statistical Institute", Publications of the American Statistical Association 4:32 (1895), 358-365.

Finn, Michael, "Stay Rates of Foreign Doctorate Recipients from U.S. Universities, 2005”, Oak Ridge Institute for Science and Education Report (2007).

Foley, C. Fritz, and William Kerr, "Ethnic Innovation and U.S. Multinational Firm Activity", Management Science 59:7 (2013), 1529-1544.

Franzoni, Chiara, Giuseppe Scellato, and Paula Stephan, "Foreign Born Scientists: Mobility Patterns for Sixteen Countries", Nature Biotechnology 30:12 (2012), 1250-1253.

Freeman, Richard, "One Ring to Rule Them All? Globalization of Knowledge and Knowledge Creation", Nordic Economic Policy Review: Globalization, Labor Market Institutions and Wage Structure. NBER Working Paper 19301 (2013). 
Freeman, Richard, and Wei Huang, "China's 'Great Leap Forward' in Science and Engineering”, in Aldo Geuna (ed.), Global Mobility of Research Scientists: The Economics of Who Goes Where and Why (Elsevier, 2015).

Gaule, Patrick, "Who Comes Back and When? Return Migration Decisions of Academic Scientists", Economics Letters 124:3 (2014), 461-464.

Gest, Justin M., Michel Beine, Anna Boucher, Brian Burgoon, Mary Crock, Michael Hiscox, Patrick McGovern, Hillel Rapoport, Joep Schaper, and Eiko Thielemann, "Measuring and Comparing Immigration, Asylum and Naturalization Policies Across Countries: Challenges and Solutions", Global Policy 5:3 (2014).

Ghani, Ejaz, William Kerr, and Christopher Stanton, "Diasporas and Outsourcing: Evidence from oDesk and India", Management Science 60:7 (2014), 1677-1697.

Ghosh, Anirban, Anna Maria Mayda, and Francesco Ortega, "The Impact of Skilled Migration on FirmLevel Productivity: An Investigation of Publicly Traded U.S. Firms", Working Paper (2016).

Gibson, John, and David McKenzie, "The Microeconomic Determinants of Emigration and Return Migration of the Best and the Brightest: Evidence from the Pacific", IZA Working Paper 3926 (2009).

Glaeser, Edward, Cities, Agglomeration and Spatial Equilibrium (Oxford: Oxford University Press, 2008).

Green, Alan, and David Green, "Canadian Immigration Policy: The Effectiveness of the Point System and Other Instruments", Canadian Journal of Economics 28:4b (1995), 1006-1041.

Grogger, Jeffrey, and Gordon Hanson, "The Scale and Selectivity of Foreign Born Ph.D. Recipients in the U.S.", American Economic Review Papers and Proceedings 103:3 (2013), 189-192.

Grogger, Jeffrey, and Gordon Hanson, "Attracting Talent: Location Choices of Foreign-Born PhDs in the United States", Journal of Labor Economics 33:S1 (2015), S5-S38.

Grossman, Gene, and Esteban Rossi-Hansberg, "Trading Tasks: A Simple Theory of Offshoring", American Economic Review 98:5 (2008), 1978-1997.

Gundel, Sebastian, and Heiko Peters, "What Determines the Duration of Stay of Immigrants in Germany? Evidence from a Longitudinal Duration Analysis", International Journal of Social Economics 35: 11 (2008), 769-782.

de Haas, Hein, Katharina Natter, and Simona Vezzoli, "Growing Restrictiveness or Changing Selection? The Nature and Evolution of Migration Policies", International Migration Review (2016).

Hanson, Gordon, William Kerr, and Sarah Turner (eds.) Talent Flows in the Global Economy, draft NBER Manuscript (2016).

Harvey, William, "British and Indian Scientists in Boston Considering Returning to Their Home Countries", Population, Space and Place 15 (2009), 493-508.

Hatzigeorgiou, Andreas, and Magnus Lodefalk, "Trade and Migration: Firm-Level Evidence", Working Paper (2011).

Hicks, John, The Theory of Wages (London: Macmillian, 1932).

Hira, Ron, "The H-1B and L-1 Visa programs: Out of Control", EPI Policy Paper (2010).

Hovhannisyan, Nune, and Wolfgang Keller, "International Business Travel: An Engine of Innovation?", Journal of Economic Growth 20:1 (2015), 75-104.

Hunt, Jennifer, "Which Immigrants are Most Innovative and Entrepreneurial? Distinctions by Entry Visa", Journal of Labor Economics 29:3 (2011), 417-457.

Hunt, Jennifer, and Marjolaine Gauthier-Loiselle, "How Much Does Immigration Boost Innovation?", American Economic Journal: Macroeconomics 2:2 (2010), 31-56.

Javorcik, Beata, Çaglar Özden, Mariana Spatareanu, and Cristina Neagu, "Migrant Networks and Foreign Direct Investment", Journal of Development Economics 94:2 (2011), 231-241.

Jones, Chad, "R\&D-Based Models of Economic Growth", Journal of Political Economy 103 (1995), 759784.

Kahn, Shulamit, and Megan MacGarvie, "How Important is U.S. Location for Research in Science?", Review of Economics and Statistics 98:2 (2016), 397-414. 
Kapur, Devesh, and John McHale, Bring Us Your Best and Brightest (Centre for Global Development, 2005).

Kato, Takao, and Chard Sparber, "Quotas and Quality: The Effect of H-1B Visa Restrictions on the Pool of Prospective Undergraduate Students from Abroad", Review of Economics and Statistics 95:1 (2013), 109-126.

Kerr, Sari, and William Kerr, "Economic Impacts of Immigration: A Survey", Finnish Economics Papers 24:1 (2011), 1-32.

Kerr, Sari, and William Kerr, "Global Collaborative Patents", Economic Journal (2015), forthcoming.

Kerr, Sari, and William Kerr, "Immigrant Entrepreneurship", NBER Working Paper 22385 (2016).

Kerr, Sari, William Kerr, and William Lincoln, "Firms and the Economics of Skilled Immigration", Innovation Policy and the Economy 15:1 (2015a), 115-152.

Kerr, Sari, William Kerr, and William Lincoln, "Skilled Immigration and the Employment Structures of U.S. Firms", Journal of Labor Economics 33:S1 (2015b), S109-S145.

Kerr, Sari, William Kerr, Çaglar Özden, and Christopher Parsons, "Global Talent Flows", Journal of Economic Perspectives 30:4 (2016), 83-106.

Kerr, William, "Ethnic Scientific Communities and International Technology Diffusion", Review of Economics and Statistics 90:3 (2008), 518-537.

Kerr, William, "Heterogeneous Technology Diffusion and Ricardian Trade Patterns", NBER Working Paper Series 19657 (2013).

Kerr, William, "U.S. High-Skilled Immigration, Innovation, and Entrepreneurship: Empirical Approaches and Evidence", in Carsten Fink and Ernest Miguelez (eds.) The International Mobility of Talent and Innovation - New Evidence and Policy Implications (Cambridge, UK: Cambridge University Press, 2016), forthcoming.

Kerr, William, and William Lincoln, "The Supply Side of Innovation: H-1B Visa Reforms and U.S. Ethnic Invention", Journal of Labor Economics 28:3 (2010), 473-508.

Kerr, William, William Lincoln, and Prachi Mishra, "The Dynamics of Firm Lobbying", American Economic Journal: Economic Policy 6:4 (2014), 343-379.

Kim, Jinyoung, and Jungsoo Park, "Foreign Direct Investment and Country-Specific Human Capital," Economic Inquiry 51:1 (2013), 198-210.

Kugler, Maurice, and Hillel Rapoport, "International Labor and Capital Flows: Complements or Substitutes?", Economics Letters 92:2 (2007), 155-162.

Kugler, Maurice, and Hillel Rapoport, "Migration, FDI and the Margins of Trade", Working Paper (2011).

Liebig, Thomas, and Jeffrey Mo, "The Fiscal Impact of Immigration in OECD Countries", in International Migration Outlook 2013 (Paris: OECD Publishing, 2013), 125-189.

Lofstrom, Magnus, and Joseph Hayes, "H-1Bs: How Do They Stack Up to US Born Workers", IZA Working Paper 6259 (2011).

Lowell, B. Lindsay, "Flows of Students, Computer Workers, and Entrepreneurs", in Immigration Policy and the Search for Skilled Workers, Summary of a Workshop (Washington, DC: National Academies Press, 2015).

Lowell, B. Lindsay, and Hal Salzman, "Into the Eye of the Storm: Assessing the Evidence on Science and Engineering Education, Quality, and Workforce Demand", Working Paper (2007).

Matloff, Norman, "On the Need for Reform of the H-1B Non-Immigrant Work Visa in Computer-Related Occupations", University of Michigan Journal of Law Reform 36:4 (2003), 815-914.

Mayda, Anna Maria, "International Migration: A Panel Data Analysis of the Determinants of Bilateral Flows", Journal of Population Economics 23:4 (2010), 1249-1274.

Miguelez, Ernest, "Inventor Diasporas and the Internationalization of Technology", CREAM Discussion Paper Series 25/14 (2014).

Miguelez, Ernest, and Carsten Fink, "Measuring the International Mobility of Inventors: A New Database”, World Intellectual Property Organization Working Paper 8 (2013). 
Miller, Paul, "Immigration Policy and Immigrant Quality: The Australian Points System", American Economic Review Papers and Proceedings 89:2 (1999), 192-197.

Moraga, Jesús Fernández-Huertas, "New Evidence on Emigrant Selection", Review of Economics and Statistics 93:1 (2011), 72-96.

Moretti, Enrico, The New Geography of Jobs (Houghton Mifflin Harcourt, 2012).

Moser, Petra, Alessandra Voena, and Fabian Waldinger, "German Jewish Émigrés and U.S. Invention", American Economic Review 104:10 (2014), 3222-3255.

Nanda, Ramana, and Tarun Khanna, "Diasporas and Domestic Entrepreneurs: Evidence from the Indian Software Industry", Journal of Economics and Management Strategy 19:4 (2010), 991-1012.

Nathan, Max, "Same Difference? Minority Ethnic Inventors, Diversity and Innovation in the UK", Journal of Economic Geography 15:1 (2015), 129-168.

National Academies, Immigration Policy and the Search for Skilled Workers (2016).

Neal, Larry, and Paul Uselding, "Immigration, a Neglected Source of American Economic Growth: 1790 to 1912", Oxford Economic Papers 24:1 (1972), 68-88.

Neeley, Tsedal, "Global Business Speaks English: Why You Need a Language Strategy Now", Harvard Business Review 90:5 (2012), 116-124.

Nejad, Maryam Naghsh, and Andrew Young, "Female Brain Drains and Women's Rights Gaps: A Gravity Model Analysis of Bilateral Migration Flows," IZA Discussion Paper 8067 (2014).

OECD, "International Migration Outlook: SOPEMI - 2008 Edition”, OECD, Paris (2008).

Oettl, Alexander, and Ajay Agrawal, "International Labor Mobility and Knowledge Flow Externalities", Journal of International Business Studies 39:8 (2008), 1242-1260.

Orrenius, Pia, and Madeline Zavodny, "Does Immigration Affect Whether US Natives Major in Science and Engineering?", Journal of Labor Economics 33:S1 (2015), S79-S108.

Özden, Çaglar, Christopher Parsons, Maurice Schiff, and Terrie Walmsley, "Where on Earth is Everybody? The Evolution of Global Bilateral Migration, 1960-2000", World Bank Economic Review 25 (2011), 12-56.

Özden, Çaglar, and David Phillips, "What Really is Brain Drain? Location of Birth, Education and Migration Dynamics of African Doctors", KNOMAD Working Paper (2015)

Özden, Çaglar, and Christopher Parsons, "On the Economic Geography of International Migration”, The World Economy, 39, (2016) 478-495.

Ozgen, Ceren, Peter Nijkamp, and Jacques Poot, "Immigration and Innovation in European Regions", IZA Working Paper 5676 (2011).

Papademetriou, Demetrios, and Madeline Sumption, Attracting and Selecting from the Global Talent Pool - Policy Challenges (Washington, D.C.: Migration Policy Institute, 2013).

Parrotta, Pierpaolo, Dario Pozzoli, and Mariola Pytlikova, "The Nexus between Labor Diversity and Firm's Innovation", Journal of Population Economics 27:2 (2014), 303-364.

Parsons, Christopher, Sebastien Rojon, Farhan Samanani, and Lena Wettach, "Conceptualising International High-Skilled Migration", International Migration Institute Working Paper Series 104 (2014).

Parsons, Christopher, and Alan Winters, "Migration, Trade and Aid: A Survey", in Robert E.B. Lucas (ed.) International Handbook on Migration and Economic Development (Edward Elgar, 2015).

Peri, Giovanni, Kevin Shih, and Chad Sparber, "STEM Workers, H-1B Visas and Productivity in US Cities", Journal of Labor Economics 33:S1 (2015), S225-S255.

Peri, Giovanni, and Chad Sparber, "Highly-Educated Immigrants and Native Occupational Choice", Industrial Relations 50:3 (2011), 385-411.

Pohl, Carsten, "Return Migration of Low- and High-Skilled Immigrants from Germany", IFO Institute for Economic Research (2006).

Rauch, James, "Business and Social Networks in International Trade", Journal of Economic Literature 39:4 (2001), 1177-1203. 
Rauch, James, and Vitor Trindade, "Ethnic Chinese Networks in International Trade", Review of Economics and Statistics 84:1 (2002), 116-130.

Rinne, Ulf, "The Evaluation of Immigration Policies", in Amelie Constant and Klaus Zimmermann (eds.) International Handbook on the Economics of Migration (Cheltenham, UK: Edward Elgar 2013), 530-551.

Rosenzweig, Mark, "Global Wage Differences and International Student Flows”, Brookings Trade Forum Global Labor Markets (2006), 57-96.

Roy, A. D., "Some Thoughts on the Distribution of Earnings", Oxford Economic Papers 3:2 (1951), 135146.

Saiz, Albert, "Immigration and Housing Rents in American Cities", Journal of Urban Economics 61:2 (2007), 345-371.

Santo Tomas, Patricia A., Lawrence Summers and Michael Clemens, "Migrants Count: Five Steps Toward Better Migration Data", Report of the Commission on International Migration Data for Development Research and Policy (Washington, DC: Centre for Global Development, 2009).

Saxenian, AnnaLee, The New Argonauts (Cambridge, MA: Harvard University Press, 2006).

Saxenian, AnnaLee, with Yasuyuki Motoyama and Xiaohong Quan, Local and Global Networks of Immigrant Professionals in Silicon Valley (San Francisco, CA: Public Policy Institute of California, 2002).

Silicon Valley Competitiveness and Innovation Report, A Dashboard and Policy Scorecard for a Shared Agenda of Prosperity and Opportunity, (Collaborative Economics, 2015).

Smith, Adam, The Wealth of Nations (1776).

Stephan, Paula, "The I's Have It: Immigration and Innovation, the Perspective from Academe", in Josh Lerner and Scott Stern (eds.) Innovation Policy and the Economy (Cambridge, MA: MIT Press, 2010).

Stephan, Paula, and Sharon Levin, "Exceptional Contributions to US Science by the Foreign-Born and Foreign-Educated", Population Research and Policy Review 20:1 (2001), 59-79.

Storesletten, Kjetil, "Sustaining Fiscal Policy through Immigration", Journal of Political Economy 108:2 (2000), 300-323.

Storesletten, Kjetil, "Fiscal Implications of Immigration: A Net Present Value Approach", Scandinavian Journal of Economics 105:3 (2003), 487-506.

Stuen, Eric, Ahmed Mobarak, and Keith Maskus, "Skilled Immigration and Innovation: Evidence from Enrollment Fluctuations in U.S. Doctoral Programs", Economic Journal 122:565 (2012), 11431176.

Wasmer, Etienne, Paul Fredriksson, Ana Lamo, Julian Messina, and Giovanni Peri, "The Macroeconomics of Education in Europe" in Brunello, Garibaldi, and Wasmer (eds.) Education and Training in Europe (Oxford: Oxford University Press, 2007).

Weinberg, Bruce, "Developing Science: Scientific Performance and Brain Drains in the Developing World", Journal of Development Economics 95:1 (2011), 95-104. 
Figures 1a and 1b. Emigrant and Immigrant Selection, 2010
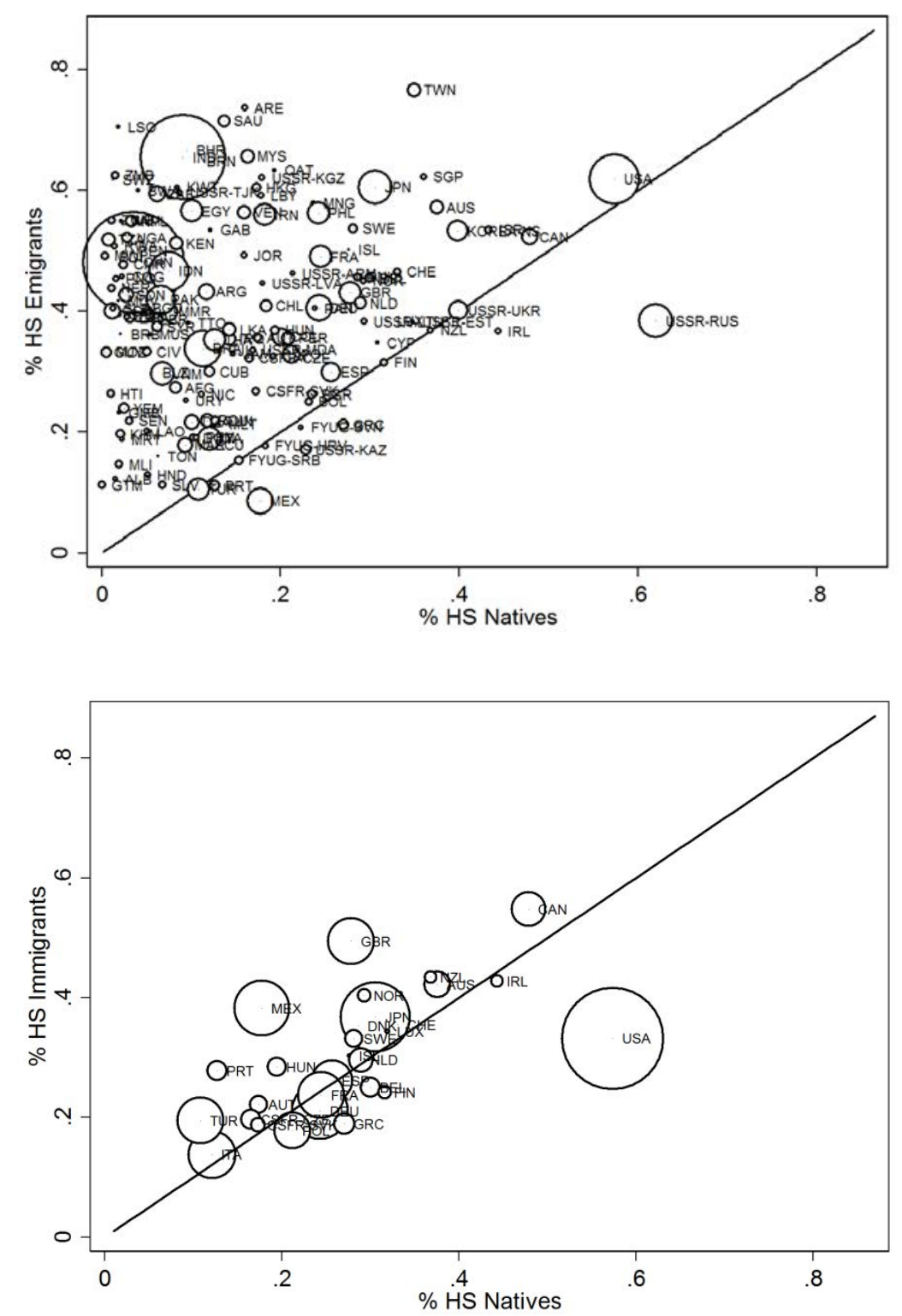

Figure 1a depicts emigrant selection from origin in 2010. Data for high-skilled natives are taken from Barro and Lee (2013). The percentage of high-skilled natives is defined as the total population aged $25+$ with any tertiary education, divided by the total population aged 25+. Data for high-skilled emigrants are taken from Arslan et al. (2014). The percentage of high-skilled emigrants is defined as the total number of tertiary-educated emigrants aged $25+$, divided by total emigration aged $25+$. Each observation is weighted by the total population at origin. The 45-degree line is shown for reference. Figure $1 \mathrm{~b}$ instead displays immigrant selection into destination in 2010. The percentage of high-skilled immigrants is defined as the total number of tertiary-educated immigrants aged $25+$, divided by total immigration aged $25+$. Each observation is weighted by the total population at destination. 
Figures 2a and 2b. Changes in Emigrant and Immigrant Selection, 1990-2010
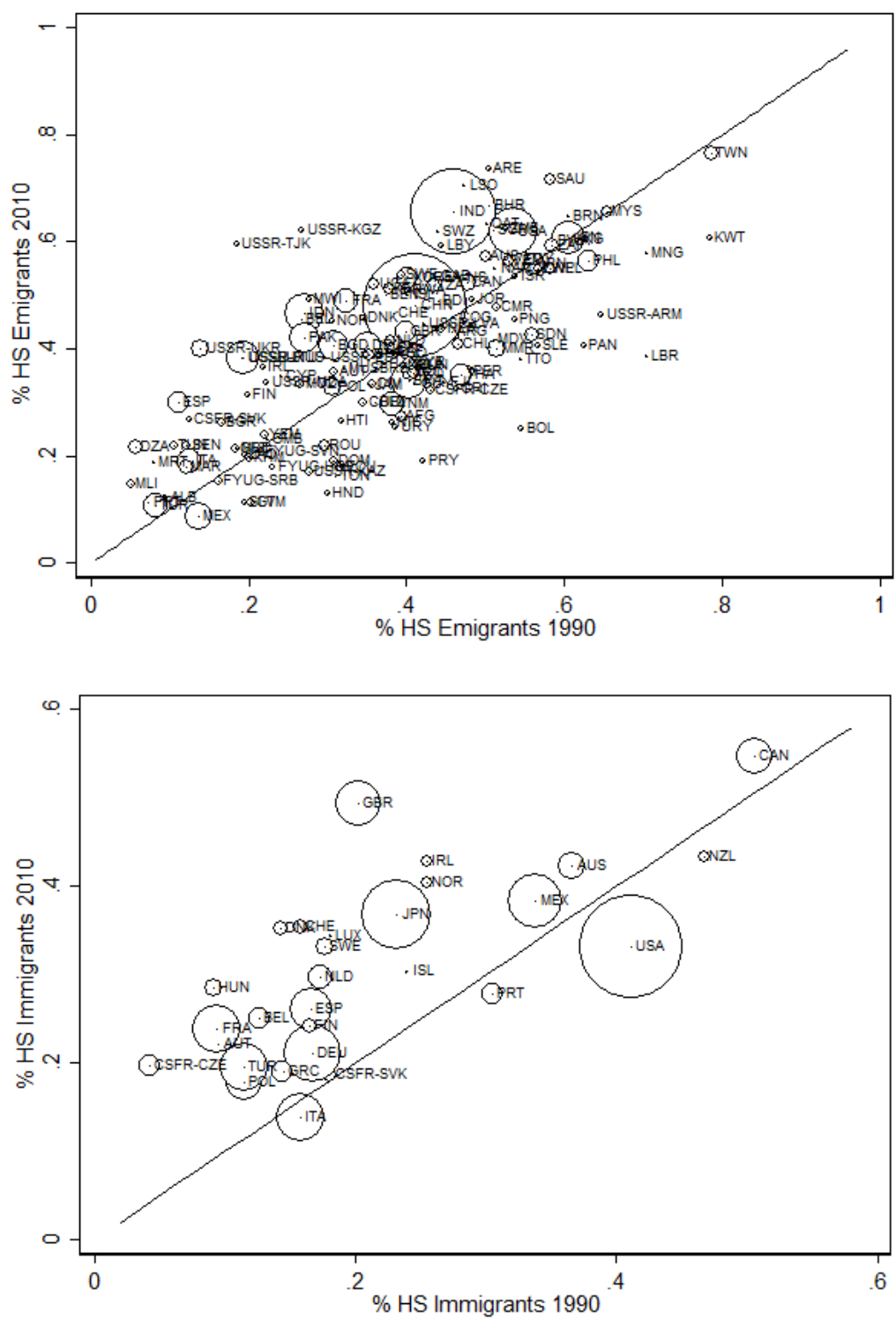

See Figures 1a and 1b. Figure 2a shows changing emigrant selection to 29 countries of the OECD between 1990 and 2010. Data are taken from matching on age (25+) and education (tertiary) those available in Docquier et al. (2009) and Arslan et al. (2014). The percentage of high-skilled emigrants is defined as the total number of tertiary-educated emigrants aged 25+, divided by total emigration aged 25+, in 1990 and 2010 respectively. The 45-degree line is shown for reference. Similarly, Figure $2 \mathrm{~b}$ demonstrates changing immigrant selection to the same countries over the period 1990-2010. The percentage of high-skilled immigrants is defined as the total number of tertiary-educated immigrants aged 25+, divided by total immigration aged 25+, in 1990 and 2010 respectively. 
Figure 3: Cumulative Distribution of Migration Distance, 2010

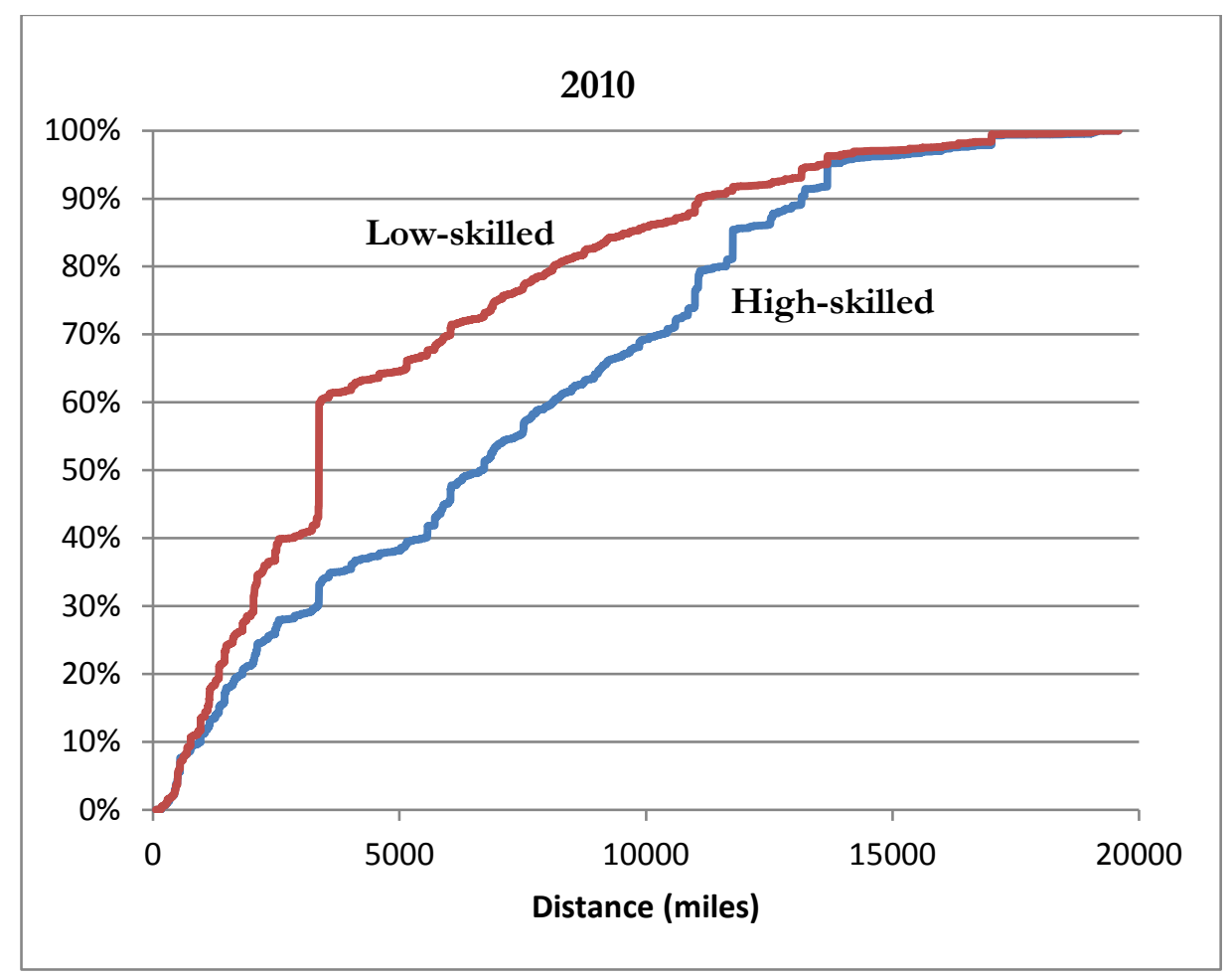

Figure 3 plots the relationship between the stock of immigrants to OECD countries and the distance between their destination and origin countries. The data come from Arslan et al. (2014) and refer to those of age 25 or over. Tertiary-educated individuals are defined as high-skilled.

Figure 4: Distribution of High-Skilled Migrants in USA, 2010

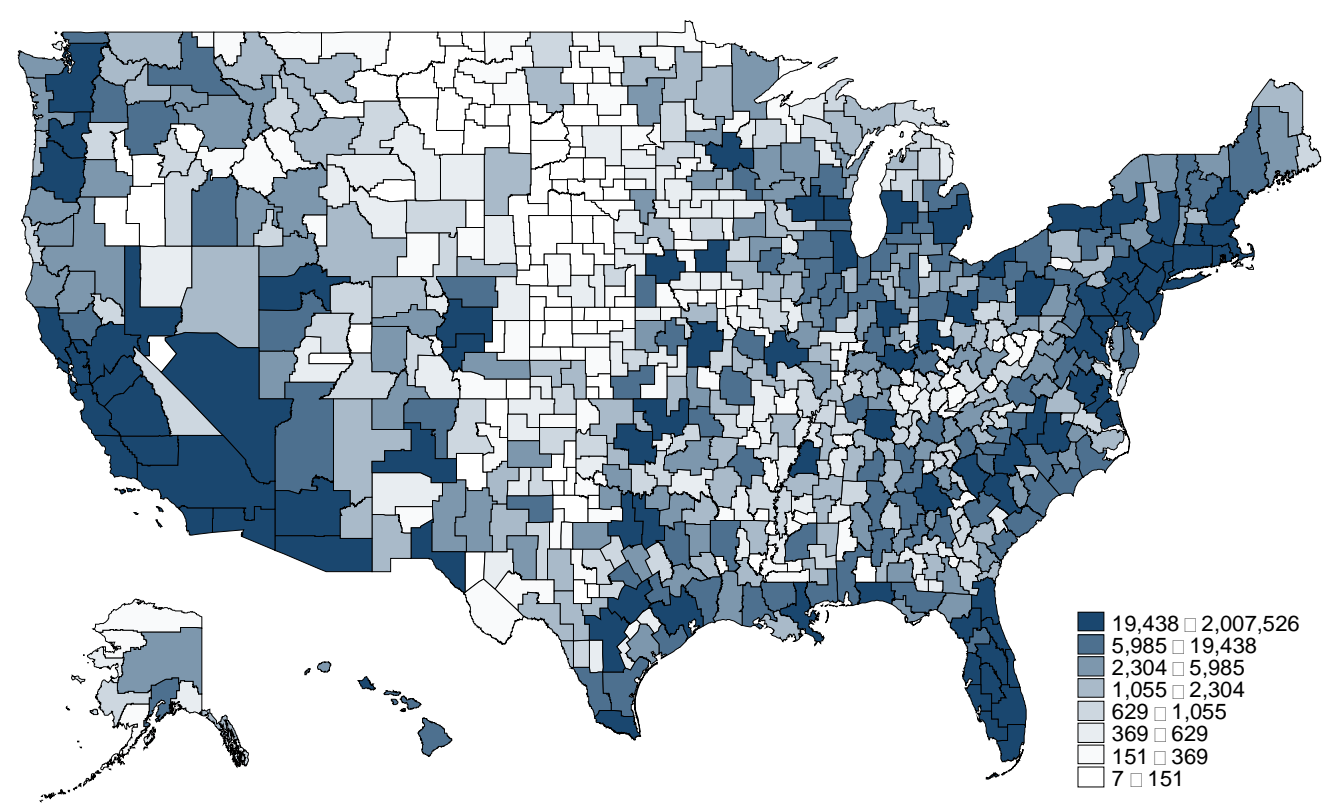

Data on high-skilled migrants by Public Use Micro Areas in 2010 are drawn from the 5-year sample of the American Community Survey. These data are subsequently merged to 1990 Commuting Zones using the crosswalk files and weights developed by David Dorn (http://www.ddorn.net/data.htm). High-skilled migrants are defined as those with at least one year of tertiary education. 


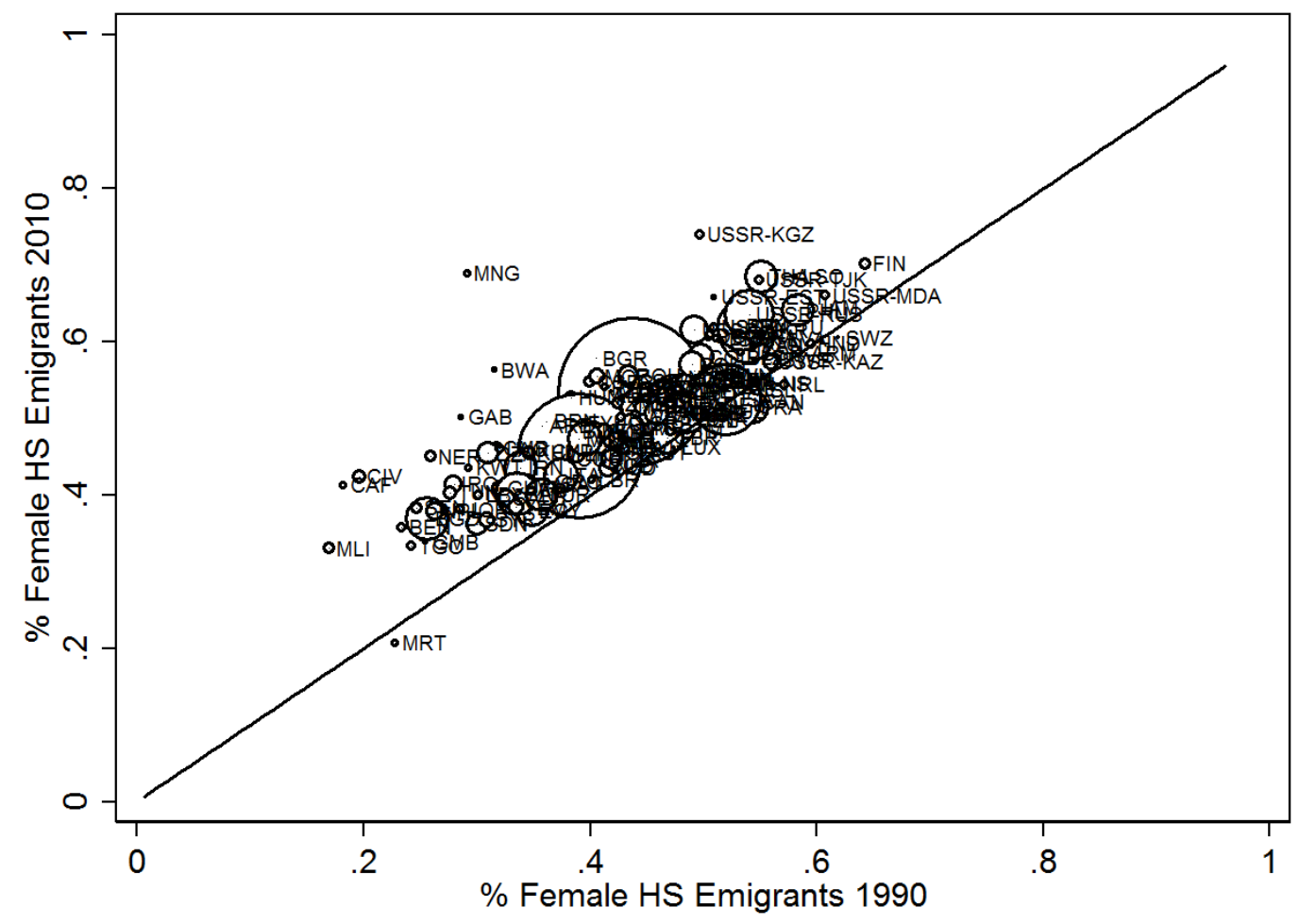

Figure 5 shows the change in selection on gender in high-skilled emigration to 29 OECD countries between 1990 and 2010. Data are taken from matching on age (25+), education (tertiary) and gender those available in Docquier et al. (2009) and Arslan et al. (2014). The percentage of female high-skilled emigrants is defined as the total number of female tertiary-educated emigrants aged $25+$, divided by total tertiary-educated emigration aged 25+, in 1990 and 2010 respectively. Each observation is weighted by the total population at origin.

\section{Figure 6: Self-Selection of Immigrants by Skill - Intermediate Case}

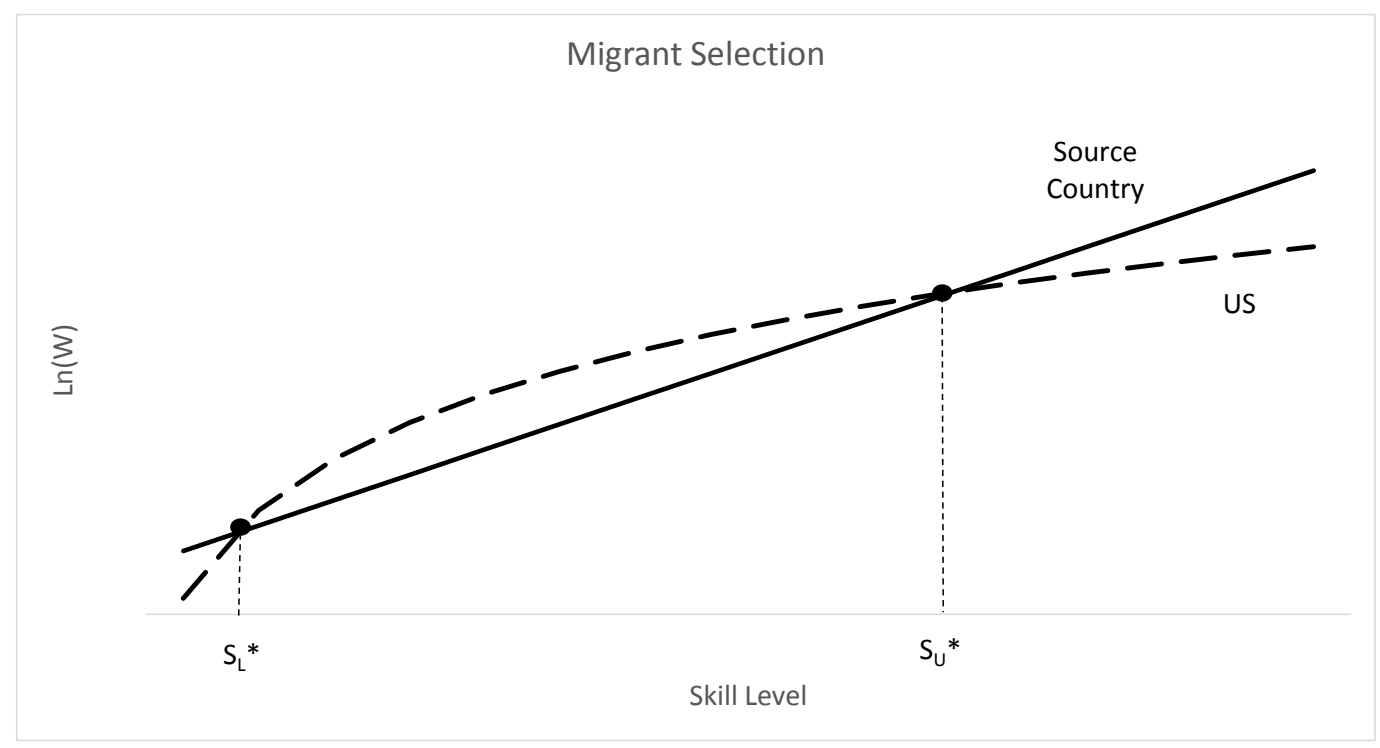

Figure 6 provides an example of intermediate selection of migrants adapted from Chiquiar and Hanson (2005) arising from non-linear returns to skill in the destination country (US) and fixed migration costs across skill groups. Individuals with a skill level between $\mathrm{SL}^{*}$ and $\mathrm{SU}^{*}$ will choose to migrate, whereas those with greater or weaker skill levels will not. 

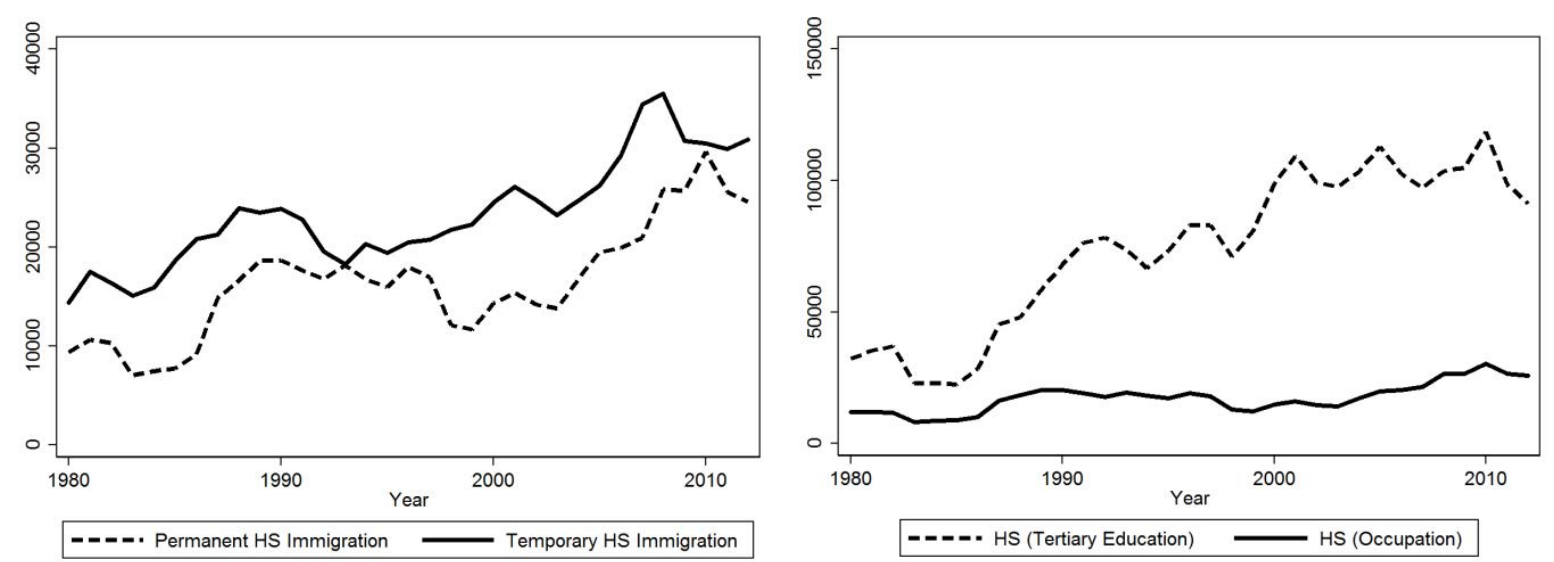

Figures $7 \mathrm{a}$ and $7 \mathrm{~b}$ highlight differences in the structure of high-skilled immigration to Canada between 1980 and 2012. Figure 7a distinguishes between high-skilled migrants' duration of stay, either temporary or permanent, taking as a definition of high skilled as being employed in an occupation in the first three categories of the International Standard Classification of Occupations (ISCO): (1) Managers, senior officials and legislators, (2) Professionals and (3) Technicians and associate professionals. Figure $7 \mathrm{~b}$ rather includes migrants of all durations of stay but distinguishes between high-skilled migrants as defined by their occupation (ISCO Categories 1-3) or attaining a tertiary education. The source of the data for both figures were obtained from Citizenship and Immigration Canada.

\section{Figures 8a and 8b: Arrivals vs. Adjusted Status in United States and United Kingdom}
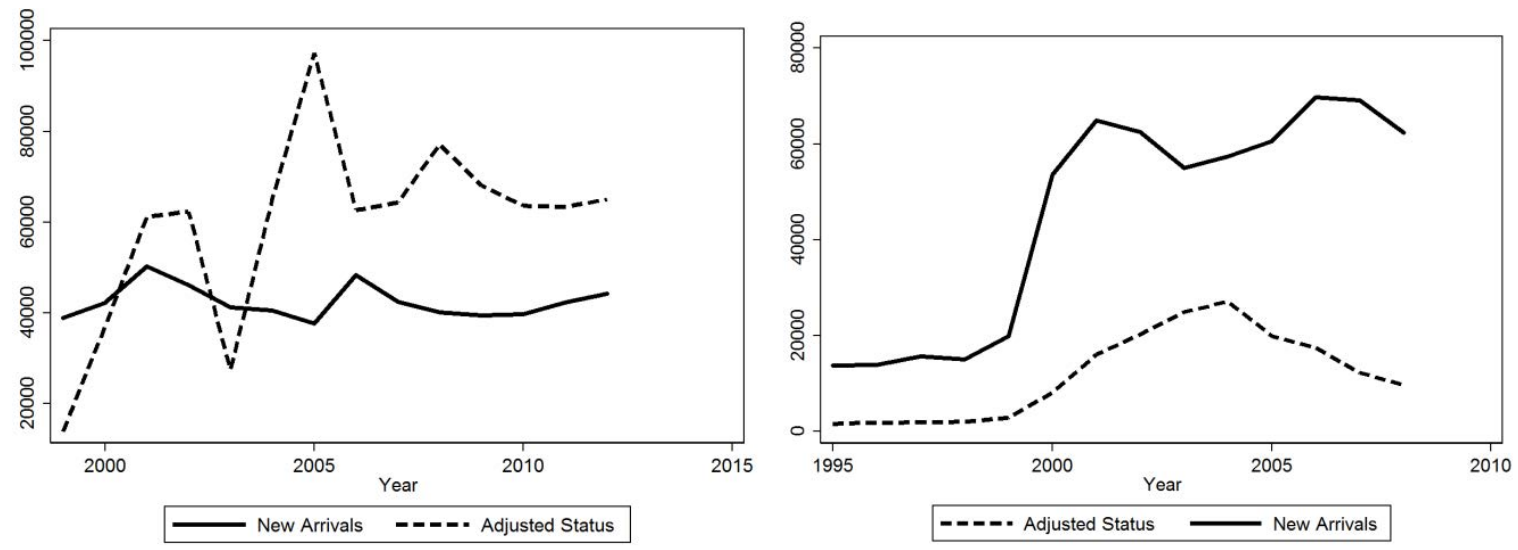

Figures $8 \mathrm{a}$ and $8 \mathrm{~b}$ highlight differences in when migration flows are actually recorded in the United States and the United Kingdom, respectively. Figure 8a therefore plots the annual rates of new arrivals into the United States as opposed to those adjusting their status, for those obtaining permanent residence as they exit from their visa status. Figure 8b similarly considers comparable data for the United Kingdom. The definition of high skilled used is being employed in an occupation in the first three categories of the International Standard Classification of Occupations (ISCO): (1) Managers, senior officials and legislators, (2) Professionals and (3) Technicians and associate professionals. The sources of the data for these figures were obtained from the Department of Homeland Security (US) and the Office of Immigration Statistics (UK). 


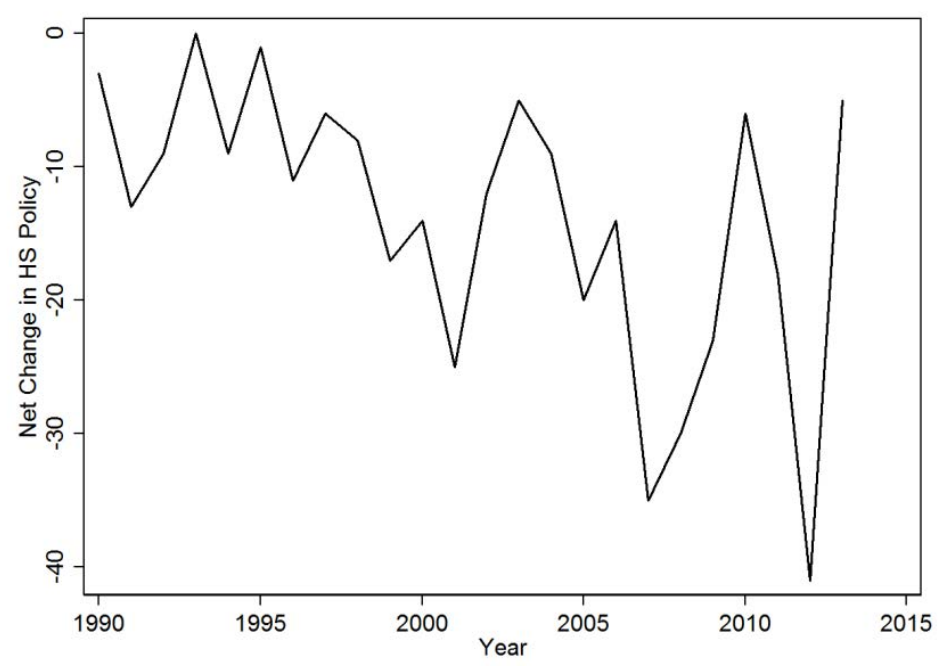

Figure 9 highlights how OECD policies toward high-skilled migrants have become more relaxed over time. The figure shows the average net weighted change in policy stance towards high-skilled migrants over the period 1990-2013. The data source is the DEMIG POLICY database.

Figures 10a and 10b: Human Capital through the Backdoor in Australia
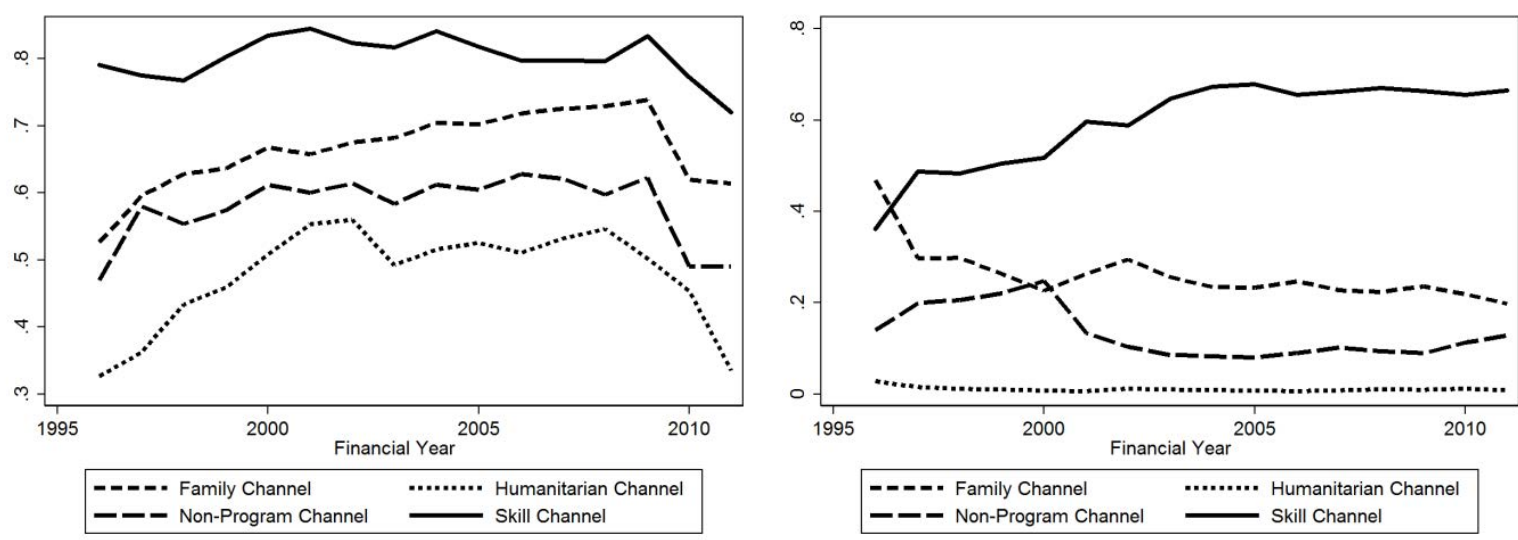

Figure 10a shows how the proportions of high-skilled migrants vary with different immigration channels in Australia. Figure 10b documents what proportions of total high-skilled migration to Australia arrive through these different immigration channels. The data detail four main channels of entry: work, family, humanitarian and non-program (largely those that previously resided in Australia without having obtained permanent settlement). Figure 10b demonstrates that at least one-third of high-skilled migrants since the late 1990s have entered Australia through a "back door" channel other than the skill channel. The definition of high skilled used is being employed in an occupation in the first three categories of the International Standard Classification of Occupations (ISCO): (1) Managers, senior officials and legislators, (2) Professionals and (3) Technicians and associate professionals. The source of the data is the Australian Department of Immigration and Border Protection. 